\title{
Prevailing climatic trends and runoff response from Hindukush-Karakoram-Himalaya, upper Indus Basin
}

\author{
Shabeh ul Hasson ${ }^{1,2}$, Jürgen Böhner ${ }^{1}$, and Valerio Lucarini ${ }^{3,4,1}$ \\ ${ }^{1}$ CEN, Centre for Earth System Research and Sustainability, University of Hamburg, Hamburg, Germany \\ ${ }^{2}$ Department of Space Sciences, Institute of Space Technology, Islamabad, Pakistan \\ ${ }^{3}$ Department of Mathematics and Statistics, University of Reading, Reading, UK \\ ${ }^{4}$ Walker Institute for Climate System Research, University of Reading, Reading, UK
}

Correspondence to: Shabeh ul Hasson (shabeh.hasson@uni-hamburg.de, shabeh.hasson@zmaw.de)

Received: 1 March 2015 - Discussion started: 23 March 2015

Revised: 11 March 2017 - Accepted: 8 April 2017 - Published: 17 May 2017

\begin{abstract}
Largely depending on the meltwater from the Hindukush-Karakoram-Himalaya, withdrawals from the upper Indus Basin (UIB) contribute half of the surface water availability in Pakistan, indispensable for agricultural production systems, industrial and domestic use, and hydropower generation. Despite such importance, a comprehensive assessment of prevailing state of relevant climatic variables determining the water availability is largely missing. Against this background, this study assesses the trends in maximum, minimum and mean temperatures, diurnal temperature range and precipitation from 18 stations (1250-4500 $\mathrm{m}$ a.s.l.) for their overlapping period of record (1995-2012) and, separately, from six stations of their long-term record (1961-2012). For this, a Mann-Kendall test on serially independent time series is applied to detect the existence of a trend, while its true slope is estimated using the Sen's slope method. Further, locally identified climatic trends are statistically assessed for their spatial-scale significance within 10 identified subregions of the UIB, and the spatially (field-) significant climatic trends are then qualitatively compared with the trends in discharge out of corresponding subregions. Over the recent period (1995-2012), we find warming and drying of spring (field-significant in March) and increasing early melt season discharge from most of the subregions, likely due to a rapid snowmelt. In stark contrast, most of the subregions feature a field-significant cooling within the monsoon period (particularly in July and September), which coincides well with the main glacier melt season. Hence, a decreasing or weakly increasing discharge is observed from the corresponding subregions during mid- to late melt season (particularly in July). Such tendencies, being largely consistent with the long-term trends (1961-2012), most likely indicate dominance of the nival but suppression of the glacial melt regime, altering overall hydrology of the UIB in future. These findings, though constrained by sparse and short observations, largely contribute in understanding the UIB melt runoff dynamics and address the hydroclimatic explanation of the "Karakoram Anomaly".
\end{abstract}

\section{Introduction}

Hydropower generation has a key importance in minimizing the ongoing energy crisis in Pakistan and meeting the country's burgeoning future energy demands. For this, seasonal water availability from the upper Indus Basin (UIB), which contributes to around half of the annual average surface water availability in Pakistan, is indispensable for exploiting $3500 \mathrm{MW}$ of installed hydropower potential at the country's largest reservoir, Tarbela, immediately downstream. With- drawals from the UIB further contribute to the country's agrarian economy by meeting extensive irrigation water demands. The earliest water supply from the UIB after a long dry period (October to March) is obtained from melting of snow (late May to late July), the extent of which largely depends upon the accumulated snow amount and the concurrent temperatures (Fowler and Archer, 2005; Hasson et al., 2014b). Snowmelt runoff is then overlapped by the glacier melt runoff (late June to late August), which pri- 
marily depends upon the melt season temperatures (Archer, 2003). Snow and glacier melt runoffs, originating from the Hindukush-Karakoram-Himalaya $(\mathrm{HKH})$ ranges, together constitute around $70-80 \%$ of the mean annual water available from the UIB (SIHP, 1997; Immerzeel et al., 2009). Unlike major river basins of South and Southeast Asia that feature extensive summer monsoonal wet regimes downstream, the lower Indus Basin is mostly arid and hyper-arid and much relies upon the meltwater from the UIB (Hasson et al., 2014b).

In view of the high sensitivity of the mountainous environments to climate change (MRI, 2015; Hasson et al., 2016b) and the role of meltwater as an important control for the UIB runoff dynamics, it is crucial to assess the prevailing climatic state of the UIB and the subsequent water availability. Several studies have been performed in this regard. For instance, Archer and Fowler (2004) found a significant increase in winter, summer and annual precipitation over the period 1961-1999. For the same period, Fowler and Archer (2006) found a significant cooling during summer but warming during winter. Sheikh et al. (2009) documented significant cooling and wetting of the monsoon (July-September) but warming of the pre-monsoon season (April-May) over the 1951-2000 period. Khattak et al. (2011) found winter warming, summer cooling (19672005), but no definite pattern for precipitation. It is noteworthy that these findings are based upon at least a decade old data records. Analyzing updated data for the last three decades (1980-2009), Bocchiola and Diolaiuti (2013) suggested that winter warming and summer cooling are less general than previously thought, and can be clearly assessed only for Gilgit and Bunji stations. They found a mostly insignificant precipitation increase over the ChitralHindukush and northwest Karakoram but a decrease over the Greater Himalayas. Analyzing temperature record for recent six decades (1952-2009), Río et al. (2013) also reported dominant warming during March and pre-monsoon season.

The abovementioned studies have analyzed observations from only a sub-set of half a dozen manual, valley-bottom, low-altitude UIB stations, which are maintained by the Pakistan Meteorological Department (PMD). In contrast to low-altitude stations, observations from high-altitude stations in South Asia mostly feature the opposite sign of climatic changes and extremes, possibly influenced by local factors (Revadekar et al., 2013). Moreover, the bulk of the UIB stream flow originates from the active hydrologic zone (2500-5500 $\mathrm{m}$ a.s.1.), when thawing temperatures migrate over and above $2500 \mathrm{~m}$ a.s.l. (SIHP, 1997). Given such a large altitudinal dependency of the climatic signals, data from the low-altitude stations, though extending back into the first half of 20th century, are not optimally representative of the hydro-meteorological conditions prevailing over the UIB frozen water resources (SIHP, 1997). Thus, the assessment of climatic trends over the UIB has so far been much restricted by the limited availability of high-altitude and most representative observations as well as their accessibility.

The abovementioned studies of Archer and Fowler (2004), Fowler and Archer (2006) and Sheikh et al. (2009) used the linear least-squares method for trend analysis. Although such parametric tests robustly assess the trend relative to nonparametric tests (Zhai et al., 2005), they need the sample data to be normally distributed, which is not always the case for hydro-meteorological observations (Hess et al., 2001). Hence, a widely adopted non-parametric test such as the Mann-Kendall test (MK - Mann, 1945; Kendall, 1975) is a more pragmatic choice, as employed by Khattak et al. (2011), Río et al. (2013) and Bocchiola and Diolaiuti (2013).

Most of the hydro-climatic time series contain red noise because of the characteristics of natural climate variability and thus are not serially independent (Zhang et al., 2000; Wang, 2008). However, the MK statistic is highly sensitive to the serial dependence of a time series (Yue and Wang, 2002; Yue et al., 2002, 2003). For instance, the variance of MK statistic $S$ increases (decreases) with the magnitude of significant positive (negative) autocorrelation of a time series, which leads to an overestimation (underestimation) of the trend detection probability (Douglas et al., 2000; Wu et al., 2008; Rivard and Vigneault, 2009). To eliminate such affect, Von Storch (1995) and Kulkarni and von Storch (1995) proposed a pre-whitening procedure that removes the lag-1 autocorrelation prior to applying the MK test, as employed by Río et al. (2013) amid the above-cited studies. However, such a procedure is particularly inefficient when a time series either features a trend or is serially dependent negatively (Rivard and Vigneault, 2009). In fact, the presence of a trend can lead to false detection of significant positive (negative) autocorrelation in a time series (Rivard and Vigneault, 2009), and removing this through a pre-whitening may remove (inflate) the portion of a trend, leading to the underestimation (overestimation) of trend detection probability and trend magnitude (Yue and Wang, 2002; Yue et al., 2003). To avoid this, Yue et al. (2002) proposed a trend-free pre-whitening (TFPW) in which the trend component of a time series is separated prior to pre-whitening and then blended back to the resultant time series, as adopted by Khattak et al. (2011). However, prior estimation of the trend may also be influenced by the presence of serial correlation in a time series in a similar way the presence of trend contaminates the estimates of autocorrelation (Zhang et al., 2000). It is, therefore, desirable to estimate the most accurate magnitudes of both the trend and autocorrelation in order to avoid the influence of one on the other.

The UIB observes contrasting hydro-meteo-cryospheric regimes mainly because of the complex HKH terrain and sophisticated interaction of prevailing regional circulations (Hasson et al., 2014a, 2016a). The sparse meteorological network in such a difficult area does not fully cover its extent either vertically or horizontally - it may also be highly influenced by complex terrain features and variability in meteorological events. Under such a scenario, tendencies as- 


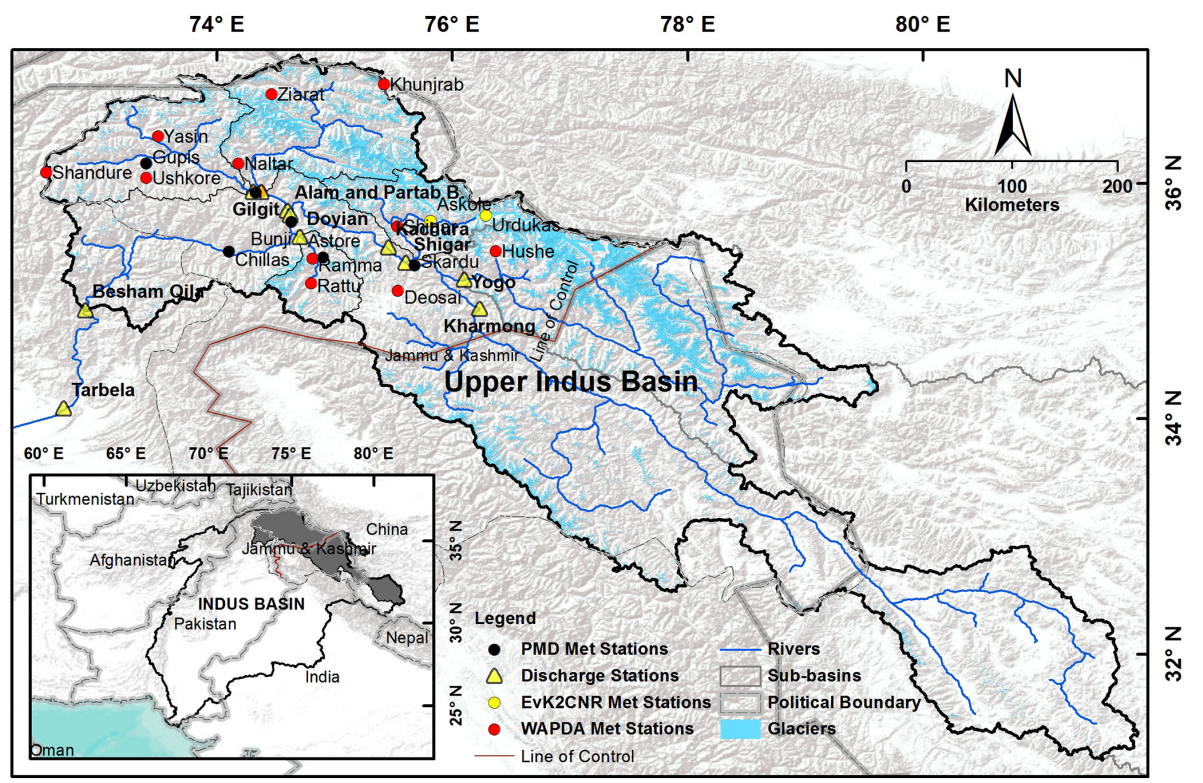

Figure 1. The upper Indus Basin (UIB) and meteorological station networks.

certained from the observations at local sites further need to be assessed for their field significance. The field significance indicates whether the stations within a particular region collectively exhibit a significant trend or not, irrespective of the significance of individual trends (Vogel and Kroll, 1989; Lacombe and McCarteny, 2014). This yields a dominant signal of change and much clear understanding of what impacts the observed conflicting climate change will have on the overall hydrology of the UIB and of its subregions. However, similar to sequentially dependent local time series, spatial/cross-correlation amid the station network of a region, possibly present due to the influence of a common climatic phenomenon and/or of similar physio-geographical features (Yue and Wang, 2002), anomalously increases the probability of detecting the field-significant trends (Yue et al., 2003; Lacombe and McCarteny, 2014). Therefore, the effect of cross-correlation amid the station network needs to be eliminated while testing the field significance (Douglas et al., 2000; Yue and Wang, 2002; Yue et al., 2003). Further, statistically identified field-significant climatic trends should be verified against the physical evidence.

In this study, we present a first comprehensive and systematic hydroclimatic trend analysis for the UIB based on 10 stream flow, 6 low-altitude manual and 12 high-altitude automatic weather stations. We apply the MK trend test over serially independent hydroclimatic time series for ensuring the existence of a trend, while its true slope is estimated by the Sen's slope method. The monthly to annual-scale individual trends are further assessed for their field significance within the 10 identified subregions of the UIB, and in order to furnish the physical attribution to statistically identified regional signal of change, the field-significant trends are in turn compared qualitatively with the trends in discharge out of the corresponding regions.

\section{Upper Indus Basin}

Spanning over the geographical range of $31-37^{\circ} \mathrm{E}$ and 72 $82^{\circ} \mathrm{N}$, the basin extends from the western Tibetan Plateau in the east to the eastern Hindukush Range in the west, hosting the Karakoram Range in the north and the western Himalayan massif (Greater Himalayas) in the south (Fig. 1). Around $46 \%$ of the UIB falls within the political boundary of Pakistan, containing around $60 \%$ of the permanent cryospheric extent. According to the Randolph Glacier Inventory version 5.0 (Arendt et al., 2015), around $12 \%$ of the UIB area $\left(19370 \mathrm{~km}^{2}\right)$ is under the glacier cover. The snow cover varies from 3 to $67 \%$ of the basin area (Hasson et al., 2014b).

The hydrology of the UIB is dominated by the precipitation regime associated with the year-round midlatitude western disturbances that intermittently transport moisture mainly during winter and spring and mostly in solid form (Wake, 1989; Ali et al., 2009; Hewitt, 2011; Hasson et al., 2016a; Hasson, 2016a). Such moisture contribution is anomalously higher during the positive phase of the North Atlantic oscillation (NAO), when the southern flank of the western disturbances intensifies over Iran and Afghanistan because of heat low there, causing additional moisture input from the Arabian Sea (Syed et al., 2006). The basin further receives moisture from the summer monsoonal offshoots, which, crossing the main barrier of the Greater Himalayas (Wake, 1989; Ali et al., 2009), precipitate over higher (lower) altitudes in solid (liquid) form (Archer and Fowler, 2004). 
Such occasional incursions of the monsoonal system and the dominating westerly disturbances - further controlled by the complex HKH terrain - define the contrasting hydroclimatic regimes within the UIB.

Mean annual precipitation within the basin ranges from less than $150 \mathrm{~mm}$ at Gilgit station to around $700 \mathrm{~mm}$ at Naltar station. However, glaciological studies suggest substantially large amounts of snow accumulations that account for 1200-1800 mm (Winiger et al., 2005) in the Bagrot valley and above $1000 \mathrm{~mm}$ over the Batura Glacier (Batura Investigations Group, 1979) within the western Karakoram. Within the central Karakoram, such amounts account for more than $1000 \mathrm{~mm}$ and, at a few sites, above $2000 \mathrm{~mm}$ over the Biafo and Hispar glaciers (Wake, 1987).

The Indus River and its tributaries are gauged at $10 \mathrm{key}$ locations within the UIB, dividing it into Astore, Gilgit, Hunza, Shigar and Shyok sub-basins, which feature distinct hydrological regimes (snow- and glacier-fed). Archer (2003) and Mukhopadhyay and Khan (2015) identified snow-fed (glacier-fed) sub-basins based on their (1) smaller (larger) glacier cover, (2) strong runoff correlation with previous winter precipitation (concurrent temperatures) from low-altitude stations, and (3) hydrograph separation. Their findings suggest that Astore and Gilgit are mainly snow-fed while Hunza, Shigar and Shyok are mainly glacier-fed sub-basins. The strong influence of climatic variables on the generated melt runoff suggests high vulnerability of spatiotemporal water availability to climatic changes. This is why the UIB discharge features high variability - in extreme cases, the maximum mean annual discharge is around an order of magnitude higher than its minimum mean annual discharge. Mean annual UIB discharge is around $2400 \mathrm{~m}^{3} \mathrm{~s}^{-1}$, which, contributing around $45 \%$ of the total surface water availability in Pakistan, is mainly confined to the melt season (AprilSeptember). For the rest of year, melting temperatures remain mostly below the active hydrologic elevation range, resulting in minute melt runoff (Archer, 2004). The characteristics of the UIB and its sub-basins are summarized in Table 1.

\section{Data}

\subsection{Meteorological data}

The network of meteorological stations within the UIB is very sparse and mainly limited to within the Pakistan's political boundary, where 20 meteorological stations are operated by three different organizations. The PMD operates six manual valley-bottom (1200-2200 m a.s.1.) stations that provide the only long-term record since the first half of the 20th century; however, the data before 1960 are scarce and feature large gaps (Sheikh et al., 2009). EvK2-CNR maintains two high-altitude stations within the central Karakoram, which provide data only starting from 2005 . The third meteorological network being maintained by the Snow and Ice Hydrology Project (SIHP) of the Water and Power Development
Authority (WAPDA), Pakistan, consists of 12 high-altitude (1479-4440 m a.s.1.) automated weather stations, called data collection platforms (DCPs), which provide observations starting from 1994. In contrast to PMD and EvK2-CNR precipitation gauges, DCPs measure snow in millimeters water equivalent as solid moisture is the main source of meltdominated hydrology of the UIB (Hasson et al., 2014b). Moreover, extending to the Karakoram Range, which hosts most of the Indus Basin ice reserves (Fig. 1), and covering most of the active hydrologic zone of the UIB (25005500 m a.s.1.) - unlike PMD stations - DCPs are well representative of the hydro-meteorological conditions prevailing over the UIB cryosphere so far. We have collected the daily data of maximum and minimum temperatures $\left(T_{x}\right.$ and $T_{n}$, respectively) and precipitation from 12 DCPs for the period 1995-2012 and from 6 PMD stations for the period 1961-2012 (Table 2).

\subsection{Discharge data}

The daily discharge data of all 10 hydrometric stations within the UIB have been collected from the Surface Water Hydrology Project of WAPDA, Pakistan, for their full length of available record up to 2012 (Table 3). Among the installed hydrometric stations, Shigar gauge has not been operational since 2001. It should be mentioned that discharge observations from the central and eastern UIB are hardly influenced by the anthropogenic perturbations. Though the western UIB is relatively populous and the stream flow is used for the single-season crops and domestic use, the overall water diversion for such use is negligible (Khattak et al., 2011).

\section{Methods}

We have checked the internal consistency of the data by closely following Klein Tank et al. (2009), such as the situations of below zero precipitation and when maximum temperature was lower than minimum temperature; these, found in only a few instances, were corrected. Thereafter, we performed homogeneity tests using a standardized toolkit RHTestV3 (Wang and Feng, 2009), which uses a penalized maximal $F$ test (Wang, 2008) to identify any number of change points in a time series. As no station has yet been reported homogeneous at monthly timescale for all variables, only a relative homogeneity test was performed by adopting the most conservative threshold level of $99 \%$ for the statistical significance. Except Skardu, PMD stations mostly feature one inhomogeneity in only $T_{n}$, which over the 1995-2012 period is valid only for Gilgit and Gupis stations (Table 2). The DCP data were found of high quality and homogeneous. Only Naltar station has experienced inhomogeneity in $T_{n}$, during September 2010, which was most probably caused by a heavy precipitation event that resulted in a mega-flood in Pakistan (Houze et al., 2011; Ahmad et al., 2012) followed by similar events in 2011 and 2012. Since station history files 
Table 1. Characteristics of the gauged and derived regions of UIB. Note: an asterisk indicates that nearby Skardu and Gilgit stations are included for the Karakoram and Deosai station for the UIB-Central regions. Derived time series are limited to a common length of record for gauges used and thus their statistics.

\begin{tabular}{|c|c|c|c|c|c|c|c|c|c|c|c|c|}
\hline $\begin{array}{l}\text { Serial } \\
\text { No. }\end{array}$ & $\begin{array}{l}\text { Watershed/ } \\
\text { Tributary }\end{array}$ & $\begin{array}{l}\text { Designated } \\
\text { discharge } \\
\text { sites }\end{array}$ & $\begin{array}{r}\text { Expression } \\
\text { for deriving } \\
\text { approximated } \\
\text { discharge }\end{array}$ & $\begin{array}{l}\text { Designated name } \\
\text { of the subregions }\end{array}$ & $\begin{array}{r}\text { Area } \\
\left(\mathrm{km}^{2}\right)\end{array}$ & $\begin{array}{r}\text { Glacier } \\
\text { cover } \\
\left(\mathrm{km}^{2}\right)\end{array}$ & $\begin{array}{r}\% \\
\text { glacier } \\
\text { cover }\end{array}$ & $\begin{array}{r}\% \text { of } \\
\text { UIB } \\
\text { glacier } \\
\text { cover }\end{array}$ & $\begin{array}{l}\text { Elevation } \\
\text { range }(\mathrm{m})\end{array}$ & $\begin{array}{r}\text { Mean } \\
\text { discharge } \\
\left(\mathrm{m}^{3} \mathrm{~s}^{-1}\right)\end{array}$ & $\begin{array}{l}\% \text { of UIB } \\
\text { discharge }\end{array}$ & $\begin{array}{r}\text { No. of } \\
\text { met } \\
\text { stations }\end{array}$ \\
\hline 1 & Indus & Kharmong & & UIB-East & 69355 & 2643 & 4 & 14 & $2250-7027$ & 451 & 18.8 & 1 \\
\hline 2 & Shyok & Yogo & & Eastern Karakoram & 33041 & 7783 & 24 & 42 & $2389-7673$ & 360 & 15.0 & 1 \\
\hline 3 & Shigar & Shigar & & Central Karakoram & 6990 & 2107 & 30 & 11 & $2189-8448$ & 206 & 8.6 & 1 \\
\hline 4 & Indus & Kachura & & Indus at Kachura & 113035 & 12397 & 11 & 68 & $2149-8448$ & 1078 & 44.8 & \\
\hline 5 & Hunza & Dainyor Bridge & & Western Karakoram & 13734 & 3815 & 28 & 21 & $1420-7809$ & 328 & 13.6 & 4 \\
\hline 6 & Gilgit & Gilgit & & Hindukush & 12078 & 818 & 7 & 4 & $1481-7134$ & 289 & 12.0 & 5 \\
\hline 7 & Gilgit & Alam Bridge & & UIB-West-upper & 27035 & 4676 & 21 & 25 & $1265-7809$ & 631 & 27.0 & 9 \\
\hline 8 & Indus & Partab Bridge & & Indus at Partab & 143130 & 17543 & 12 & 96 & $1246-8448$ & 1788 & 74.3 & \\
\hline 9 & Astore & Doyian & & Astore at Doyian & 3903 & 527 & 14 & 3 & $1504-8069$ & 139 & 5.8 & 3 \\
\hline 10 & UIB & Besham Qila & & UIB & 163528 & 19370 & 12 & 100 & $569-8448$ & 2405 & 100.0 & 18 \\
\hline 11 & & & $4-2-1$ & Shigar region & & & & & & 305 & 12.7 & \\
\hline 12 & & & $2+3+5$ & Karakoram & 53765 & 13705 & 25 & 75 & $1420-8448$ & 894 & 37.2 & $8^{*}$ \\
\hline 13 & & & $2+11+5$ & derived Karakoram & & & & & & 993 & 41.3 & \\
\hline 14 & & & $4-1$ & UIB-Central & 43680 & 9890 & 23 & 54 & $2189-8448$ & 627 & 26.1 & $4^{*}$ \\
\hline 15 & & & $10-4$ & UIB-West & 50500 & 5817 & 13 & 32 & $569-7809$ & 1327 & 55.2 & 14 \\
\hline 16 & & & $10-4-7$ & UIB-West-lower & 23422 & 1130 & 7 & 6 & $569-8069$ & 696 & 28.9 & 5 \\
\hline 17 & & & $1+16$ & Himalaya & 92777 & 3773 & 5 & 20 & $569-8069$ & 1147 & 47.7 & 7 \\
\hline
\end{tabular}

Table 2. Meteorological stations and their attributes. Inhomogeneity is found only in $T_{n}$ over full period of record. Note: asterisk represents inhomogeneity only over the 1995-2012 period.

\begin{tabular}{lllllcccl}
\hline $\begin{array}{l}\text { Serial } \\
\text { No. }\end{array}$ & $\begin{array}{l}\text { Station } \\
\text { name }\end{array}$ & $\begin{array}{l}\text { Period } \\
\text { from }\end{array}$ & $\begin{array}{l}\text { Period } \\
\text { to }\end{array}$ & Agency & $\begin{array}{c}\text { Latitude } \\
\left({ }^{\circ}\right)\end{array}$ & $\begin{array}{c}\text { Longitude } \\
\left({ }^{\circ}\right)\end{array}$ & $\begin{array}{c}\text { Altitude } \\
(\mathrm{m})\end{array}$ & $\begin{array}{l}\text { Inhomogeneity } \\
\text { at }\end{array}$ \\
\hline 1 & Chillas & 1 Jan 1962 & 31 Dec 2012 & PMD & 35.42 & 74.10 & 1251 & $2009 / 2003$ \\
2 & Bunji & 1 Jan 1961 & 31 Dec 2012 & PMD & 35.67 & 74.63 & 1372 & $1977 / 2011$ \\
3 & Skardu & 1 Jan 1961 & 31 Dec 2012 & PMD & 35.30 & 75.68 & 2210 & \\
4 & Astore & 1 Jan 1962 & 31 Dec 2012 & PMD & 35.37 & 74.90 & 2168 & $1981 / 2008$ \\
5 & Gilgit & 1 Jan 1960 & 31 Dec 2012 & PMD & 35.92 & 74.33 & 1460 & 2003/2010* \\
6 & Gupis & 1 Jan 1961 & 31 Dec 2010 & PMD & 36.17 & 73.40 & 2156 & $1988 / 2012$ \\
& & & & & & & & $1996 / 2007^{*}$ \\
7 & Khunjrab & 1 Jan 1995 & 31 Dec 2012 & WAPDA & 36.84 & 75.42 & 4440 & \\
8 & Naltar & 1 Jan 1995 & 31 Dec 2012 & WAPDA & 36.17 & 74.18 & 2898 & $2010 / 2009^{*}$ \\
9 & Ramma & 1 Jan 1995 & 30 Sep 2012 & WAPDA & 35.36 & 74.81 & 3179 & \\
10 & Rattu & 29 Mar 1995 & 16 Mar 2012 & WAPDA & 35.15 & 74.80 & 2718 & \\
11 & Hushe & 1 Jan 1995 & 31 Dec 2012 & WAPDA & 35.42 & 76.37 & 3075 & \\
12 & Ushkore & 1 Jan 1995 & 31 Dec 2012 & WAPDA & 36.05 & 73.39 & 3051 & \\
13 & Yasin & 1 Jan 1995 & 6 Oct 2010 & WAPDA & 36.40 & 73.50 & 3280 & \\
15 & Ziarat & 1 Jan 1995 & 31 Dec 2012 & WAPDA & 36.77 & 74.46 & 3020 & \\
16 & Dainyor & 15 Jan 1997 & 31 Jul 2012 & WAPDA & 35.93 & 74.37 & 1479 & \\
17 & Dendoor & 1 Jan 1995 & 28 Dec 2012 & WAPDA & 36.09 & 72.55 & 3712 & \\
18 & Shigar & 27 Aug 1998 & 31 Dec 2011 & WAPDA & 35.09 & 75.54 & 4149 & \\
\hline
\end{tabular}

were not available, it was not sure that any statistically found inhomogeneity only in $T_{n}$ is real. Thus, we did not apply corrections to inhomogeneous time series and caution that results should be interpreted carefully based on them.

\subsection{Hydroclimatic trend analysis}

We have analyzed trends in minimum, maximum and mean temperatures $\left(T_{n}, T_{x}\right.$ and $T_{\mathrm{avg}}$, respectively), diurnal temper- ature range $\left(\mathrm{DTR}=T_{x}-T_{n}\right)$, precipitation and discharge on monthly to annual timescales. For this, the MK test (Mann, 1945; Kendall, 1975) is applied to assess the existence of a trend, while the Theil-Sen (TS - Theil, 1950; Sen, 1968) slope method is applied to estimate its true slope. The MK is a rank-based method that tests the existence of a trend irrespective of the type of sample data distribution and whether such a trend is linear or not (Wu et al., 2008; Tabari and Talaee, 2011). MK is also insensitive to the data outliers 
Table 3. SWHP WAPDA stream flow gauges given in the downstream order along with their characteristics and their periods of record analyzed. Asterisk indicates gauge is not operational after 2001.

\begin{tabular}{lllclcrr}
\hline $\begin{array}{l}\text { Serial } \\
\text { No. }\end{array}$ & $\begin{array}{l}\text { Gauged } \\
\text { river }\end{array}$ & $\begin{array}{l}\text { Discharge } \\
\text { gauging site }\end{array}$ & $\begin{array}{c}\text { Period } \\
\text { from }\end{array}$ & $\begin{array}{l}\text { Period } \\
\text { to }\end{array}$ & $\begin{array}{c}\text { Latitude } \\
\left({ }^{\circ}\right)\end{array}$ & $\begin{array}{r}\text { Longitude } \\
\left({ }^{\circ}\right)\end{array}$ & $\begin{array}{r}\text { Height } \\
(\mathrm{m})\end{array}$ \\
\hline 1 & Indus & Kharmong & May 1982 & Dec 2011 & 34.93 & 76.21 & 2542 \\
2 & Shyok & Yogo & Jan 1974 & Dec 2011 & 35.18 & 76.10 & 2469 \\
3 & Shigar & Shigar* & Jan 1985 & Dec 1998 and 2001 & 35.33 & 75.75 & 2438 \\
4 & Indus & Kachura & Jan 1970 & Dec 2011 & 35.45 & 75.41 & 2341 \\
5 & Hunza & Dainyor & Jan 1966 & Dec 2011 & 35.92 & 74.37 & 1370 \\
6 & Gilgit & Gilgit & Jan 1970 & Dec 2011 & 35.92 & 74.30 & 1430 \\
7 & Gilgit & Alam Bridge & Jan 1974 & Dec 2012 & 35.76 & 74.59 & 1280 \\
8 & Indus & Partab Bridge & Jan 1962 & Dec 2007 & 35.73 & 74.62 & 1250 \\
9 & Astore & Doyian & Jan 1974 & Aug 2011 & 35.54 & 74.70 & 1583 \\
10 & UIB & Besham Qila & Jan 1969 & Dec 2012 & 34.92 & 72.88 & 580 \\
\hline
\end{tabular}

and missing values (Bocchiola and Diolaiuti, 2013) and less sensitive to the breaks caused by inhomogeneous time series (Jaagus, 2006). For comparison between low- and highaltitude stations, we have mainly analyzed their overlapping period of record (1995-2012) but additionally the full period of record (1961-2012) for the low-altitude stations.

\subsection{Trend-perceptive pre-whitening}

The applied approach of Zhang et al. (2000) assumes that the trend can be approximated as linear (Eq. 1) and the noise, $\gamma_{t}$, can be represented as a $p$ th-order autoregressive process, $\operatorname{AR}(p)$, of the signal itself, plus the white noise, $\varepsilon_{t}$. Since the partial autocorrelations for lags larger than one are generally found insignificant (Zhang et al., 2000; Wang and Swail, 2001), considering only lag-1 autoregressive processes, $r$, transforms Eq. (1) into Eq. (2):

$Y_{t}=a+\beta t+\gamma_{t}$,

$Y_{t}=a+\beta t+r Y_{t-1}+\varepsilon_{t}$.

Then the most accurate magnitudes of lag-1 autocorrelation and trend are iteratively found using the following steps:

1. in the first iteration, lag-1 autocorrelation, $r_{1}$ is computed on the original time series, $Y_{t}$;

2. using $r_{1}$ as $\left(Y_{t}-r \cdot Y_{t-1}\right) /(1-r)$, the intermediate time series, $\hat{Y}_{t}$, is obtained and its trend, $\beta_{1}$, is computed using TS and MK methods;

3. the original time series, $Y_{t}$, is detrended using $\beta_{1}$ as $\left(\hat{Y}_{t}=Y_{t}-\beta_{1} t\right)$;

4. in the second iteration, lag-1 autocorrelation, $r_{2}$, is estimated on a detrended time series, $\hat{Y}_{t}$;

5. the original time series, $Y_{t}$, is again pre-whitened using $r_{2}$ and $\hat{Y}_{t}$ is obtained;
6. the trend, $\beta_{2}$, is then computed on $\hat{Y}_{t}$ and $Y_{t}$ is detrended again, yielding $\hat{Y}_{t}$.

The steps have to be reiterated until $r$ is no longer significantly different from zero or the absolute difference between the estimates of $r, \beta$ obtained from two consecutive iterations becomes less than $1 \%$. If any of the conditions are met, let us suppose that, at the iteration $n$, the estimates from previous iteration (i.e., $r=r_{n-1}, \beta=\beta_{n-1}$ ) are used in Eq. (3) to obtain a pre-whitened time series, $Y_{t}^{w}$, which features the same trend as of the original time series, $Y_{t}$ (Zhang et al., 2000; Wang and Swail, 2001).

$$
\begin{aligned}
Y_{t}^{w}= & \frac{\left(Y_{t}-r \cdot Y_{t-1}\right)}{(1-r)}=\hat{a}+\beta t+\epsilon_{t}, \\
& \text { where } \hat{a}=a+\frac{r \cdot \beta}{(1-r)}, \text { and } \epsilon_{t}=\frac{\varepsilon_{t}}{(1-r)}
\end{aligned}
$$

\subsection{Field significance and physical attribution}

Field significance indicates whether two or more stations within a particular region collectively exhibit a significant trend, irrespective of the significance of their individual trends (Vogel and Kroll, 1989; Lacombe and McCarteny, 2014). The field significance of climatic variables has been assessed for the 10 subregions of the UIB identified based on (1) distinct hydrological regimes, (2) mountain divides, and (3) installed hydrometric stations. Further, in order to establish more confidence, statistically identified field-significant climatic trends were qualitatively compared to the physically based evidence of trend in discharge out of the corresponding region. As outlet discharges describe the integrated signal of hydrologic change within the basin, testing their field significance was not required.

The Shigar has continuous discharge only until 1998, where its post-1998 discharge needs to be derived. For this, Mukhopadhyay and Khan (2014) estimated the pre-1998 monthly correlation coefficients between Shigar and its immediate downstream Kachura gauge and applied these coef- 
ficients to the post-1998 Kachura discharge. However, such an approach yields merely a constant fraction of the Kachura discharge as the coefficients applied are less likely to remain invariant after 1998, in view of the large drainage area of Indus at Kachura $\left(113000 \mathrm{~km}^{2}\right)$ and the hydroclimatic changes expected upstream of the Shigar gauge. Here, instead of estimating the post-1998 discharge at the Shigar gauge, we have derived the discharge for the Shigar region, which comprises the Shigar sub-basin itself plus the adjacent region shown unhighlighted in Fig. 2. This was achieved by subtracting the discharge rates of all gauges upstream Shigar gauge from its immediate downstream gauge of Kachura, for each time step of every timescale analyzed. The procedure assumes that the gauges far from each other have negligible routing time delay at the analyzed mean monthly timescale and that such approximation does not further influence the ascertained trends. Similar approach was adopted to derive discharges out of ungauged identified subregions (Table 1).

We have considered the combined drainage area of Shyok and Shigar region as UIB-Central and the drainage area of Indus at Kharmong as UIB-East (Fig. 2). The rest of the UIB is designated UIB-West (Fig. 2), which is further divided into upper and lower parts due to their distinct hydrological regimes. Here, these regimes are identified based on the timings of maximum runoff production from the median hydrographs of each hydrometric station. According to such division, UIB-West-lower and Gilgit are mainly the snowfed, while Hunza is mainly glacier-fed (Fig. 3). Since the most of the Gilgit Basin area lies at the Hindukush massifs, we refer to it as the Hindukush region. The combined area of UIB-West-lower and UIB-East mainly contains the northward slopes of the Greater Himalayas, so we call it Himalaya. Similarly, drainage areas of Hunza, Shyok and Shigar region are referred to as western, eastern and central Karakoram, respectively, which collectively constitute the Karakoram region.

For assessing the field significance, we have applied the method of Yue et al. (2003), which preserves the crosscorrelation amid the stations network but eliminates its effect on testing the field significance through resampling the original network using bootstrapping approach (Efron, 1979), in our case 1000 times. The method considers the counts of significant trends as the representative variables. Unlike MK statistics, $S$ or its regional average (Douglas et al., 2000; Yue and Wang, 2002) "counts" variable favorably provides a measure of dominant field-significant trend when both positive and negative significant trends are present. The method counts both the number of local significant positive trends and the number of significant negative trends separately for each of 1000 resampled networks using Eq. (10):

$C_{f}=\sum_{i=1}^{n} C_{i}$, where $n$ denotes total number of stations within a region and $C_{i}$ denotes a count for a statistically significant trend (at the $90 \%$ level) at station $i$. Then, the empirical cumulative distributions $C_{f}$ were obtained for both counts of significant positive trends and counts of significant negative trends, by ranking their 1000 values in an ascending order using Eq. (11):

$P\left(C_{f} \leq C_{f}^{r}\right)=\frac{r}{N+1}$

where $r$ is the rank of $C_{f}^{r}$ and $N$ denotes the total number of resampled network datasets. We have estimated the probability of counts of significant positive (negative) trends in an actual network by comparing the number with $C_{f}$ for counts of significant positive (negative) trends obtained from resampled networks (Eq. 12).

$$
\begin{gathered}
P_{\mathrm{obs}}=P\left(C_{f, \mathrm{obs}} \leq C_{f}^{r}\right), \\
P_{f}=\left\{\begin{array}{lll}
P_{\mathrm{obs}} & \text { where } & P_{\mathrm{obs}} \leq 0.5 \\
1-P_{\mathrm{obs}} & \text { for } \quad P_{\mathrm{obs}}>0.5
\end{array}\right.
\end{gathered}
$$

If $P_{f} \leq 0.1$ is satisfied, the trend for a region is considered to be field-significant at the $90 \%$ level.

We have intentionally avoided the interpolation of data and results in view of the limitations of interpolation techniques in HKH complex terrain. A large offset of glaciological estimates from the station-based precipitation amounts (Hasson et al., 2014b) further suggests that the hydroclimatic patterns are highly variable in space and that the interpolation will add to uncertainty, resulting in misleading conclusions.

\section{Results}

Results for the 1995-2012 period are presented in Tables 4 and 5 (and for select months in Fig. 4), while Table 6 presents results for the 1961-2012 period. Field-significant climatic and discharge trends of corresponding regions are given in Table 7.

\subsection{Hydroclimatic trends}

\subsubsection{Mean maximum temperature}

During the months of March, May and November, most of the stations suggest mostly insignificant warming, which, in terms of magnitude and significance, dominates during March and at the low-altitude stations (Table 4 and Fig. 4). In contrast, during the monsoon (July-October) and in February, most of the stations suggest cooling, which, being similar in magnitude among low- and high-altitude stations, dominates in September followed by July in terms of both magnitude and statistical significance (at 12 and 5 stations, respectively). Moreover, the observed cooling dominates the observed warming. For the rest of the months, there is a mixed response of mostly insignificant cooling and warming trends. On a typical seasonal scale, there is high agreement on spring 


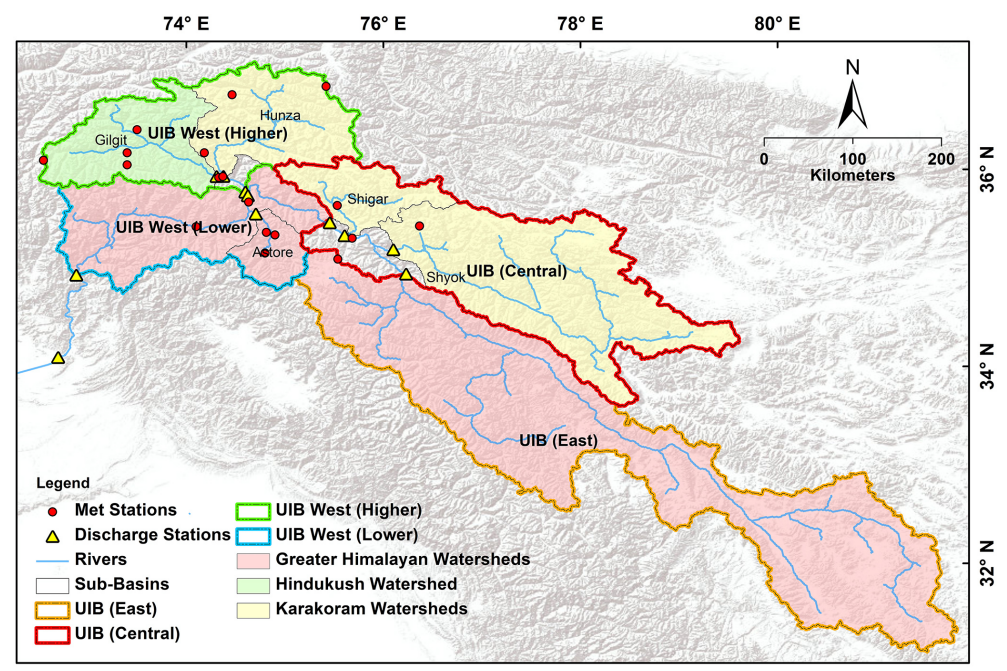

Figure 2. Hydrometric stations and the subregions considered for field significance.

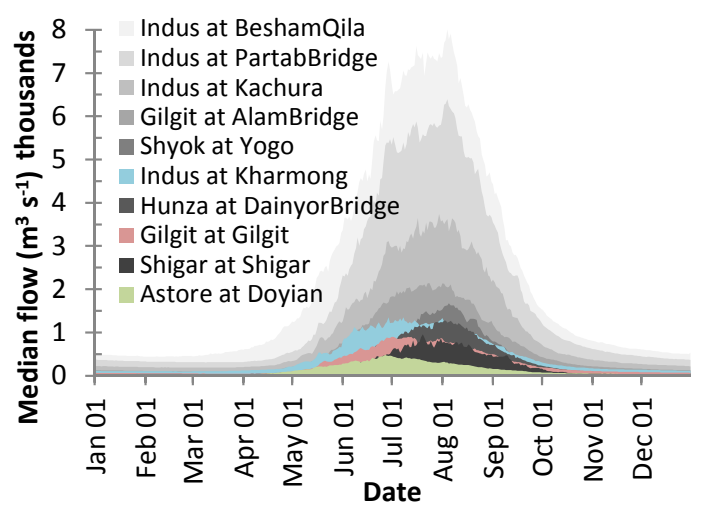

Figure 3. Long-term median hydrograph for 10 gauges separating the sub-basins of the UIB featuring either mainly snow-fed (in color) or glacier-fed (in greyscale) hydrological regimes.

warming and summer and autumn cooling but a mixed response for winter and annual timescales.

While looking only at long-term trends (Table 6), we note that summer cooling (warming outside summer) in $T_{x}$ is less (more) prominent and insignificant (significant) at relatively high-altitude stations, such as Skardu, Gupis, Gilgit and Astore. When compared with trends over the shorter period of 1995-2012, strong long-term warming is restricted to spring months mainly during March and May. Similarly, long-term summer cooling period of June-September has been shifted to July-October.

\subsubsection{Mean minimum temperature}

The dominant feature of $T_{n}$ is November-June insignificant warming, which, contrary to warming in $T_{x}$, is observed higher at the high-altitude stations than at the low-altitude stations (Table 4 and Fig. 4). In contrast to August cooling in $T_{x}$, stations suggest a minute and mostly insignificant warming in $T_{n}$. In contrast to mostly insignificant warming, we have also found cooling in $T_{n}$ during the months of July, September and October, which, though similar in magnitude among low- and high-altitude stations, dominates in September followed by July (significant at eight and four stations, respectively) as well as over the general $T_{n}$ warming, similar to $T_{x}$.

On a typical seasonal scale, our results suggest warming during winter and spring, cooling during summer and a mixed response for the autumn season. The observed warming dominates during spring. It is noted that a clear signal of significant September cooling was lost when trend was assessed on seasonally averaged observations for autumn (combining October and November months). This is further notable from the annual timescale, on which warming trends (significant at five stations) dominate instead of cooling trends.

While looking only at low-altitude stations (Table 6), we note that long-term non-summer warming (summer cooling) in $T_{n}$ is less (more) prominent and insignificant (significant) at stations of relatively high altitude, such as Skardu, Gupis, Gilgit and Astore. The long-term warming of winter months is mostly absent over the period 1995-2012.

\subsubsection{Mean temperature}

Trends in $T_{\text {avg }}$ are dominated by trends in $T_{x}$ during the July-October period and by $T_{n}$ during the rest of year (Tables 4 and 5). Similar to $T_{x}, T_{\text {avg }}$ features dominant cooling in September, followed by July and October (significant at 10, 4 and 1 stations, respectively). In contrast, warming dominates in March, which is significant at five stations. Additionally, insignificant warming tendencies observed in May 


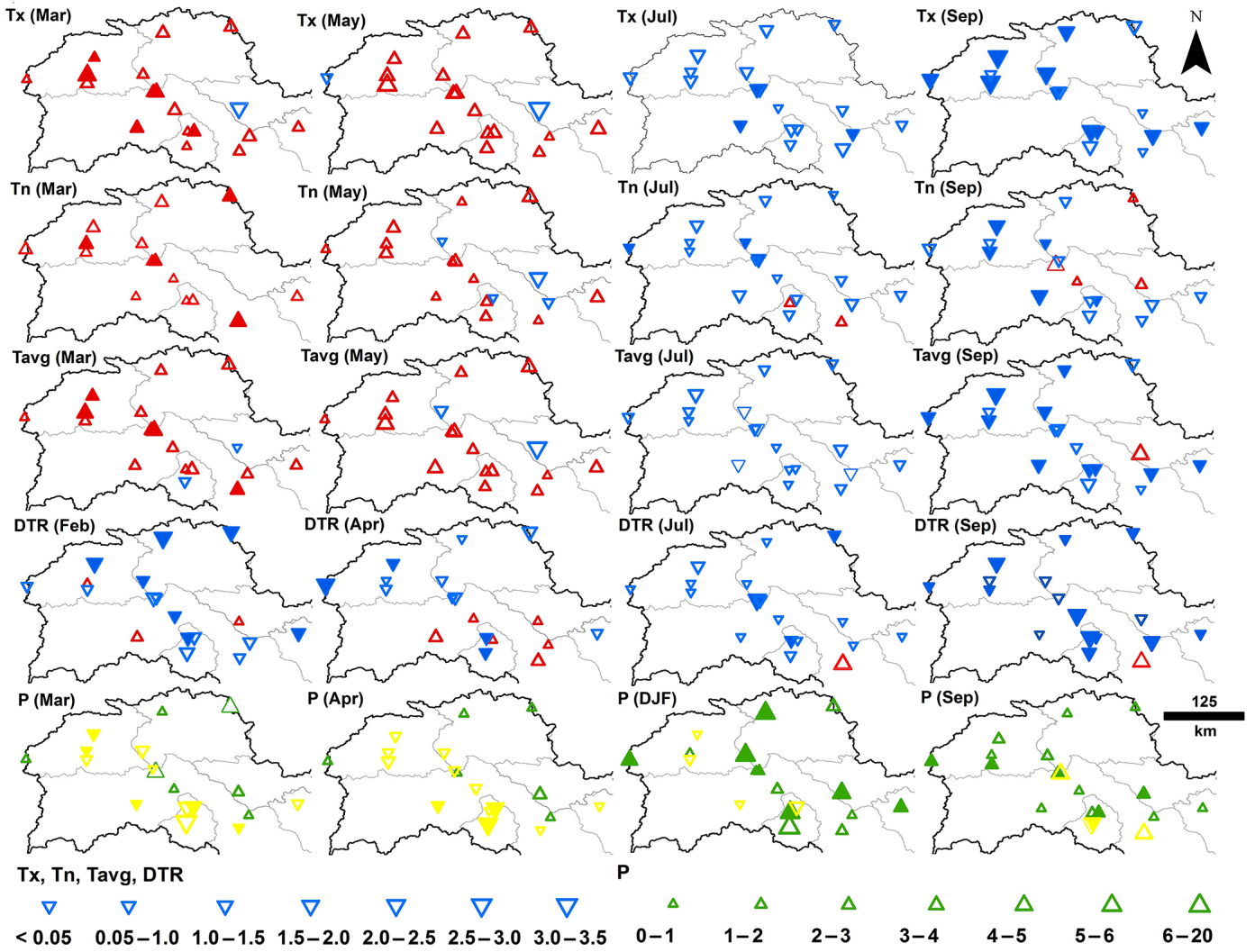

Figure 4. Trends per decade in $T_{x}, T_{n}, T_{\text {avg }}$, DTR $\left({ }^{\circ} \mathrm{C}\right)$ and trends per time step in $P(\mathrm{~mm})$ for select months and seasons. Triangles pointing upward (downward) or in green/red (blue/yellow) show increasing (decreasing) trends. Solid (hollow) triangles indicate significant (insignificant) trends at the $90 \%$ level.

and November show good agreement among most of the stations (Table 5, Fig. 4). On a typical seasonal timescale, the magnitude of winter and spring warming is observed higher than that of summer and autumn cooling, leading to dominant though mostly insignificant warming on annual timescale. The long-term trends generally suggest cooling tendencies for the June-October period but warming for the rest of year. On a seasonal timescale, low-altitude stations all show agreement on long-term and mostly significant summer cooling. For the annual timescale, a mixed response is found.

\subsubsection{Diurnal temperature range}

DTR is generally found narrowing throughout the year except for March and May, where particularly low-altitude stations suggest its widening owing to either higher $T_{x}$ warming or higher $T_{n}$ cooling (Table 4, Fig. 4). With high inter-station agreement, narrowing of DTR is particularly significant in September followed by February and associated with higher cooling in $T_{x}$ than in $T_{n}$, higher warming in $T_{n}$ than in $T_{x}$ or cooling in $T_{x}$ but warming in $T_{n}$. Narrowing DTR is more prominent at high-altitude stations and during winter, autumn and annual timescales. We note that the long-term (19612012) year-round DTR widening observed at low-altitude stations (Table 6) is mainly restricted to March and May and, to some extent, October and December over the period 19952012 (Table 4).

\subsubsection{Total precipitation}

Generally, the months of March-June feature decreasing precipitation trends, which are significant at seven, five, two and four stations, respectively (Table 5 and Fig. 4). Similarly, significant drying is observed during August and October at three stations, while Rattu station suggests yearround drying except in January and February. High interstation agreement is observed for increasing September and winter precipitation, which is higher at high-altitude than at low-altitude stations. Most of the stations within the UIBWest-upper (monsoon-dominated region) exhibit an increasing trend. Six stations (Shendure, Yasin, Ziarat, Rattu, Shigar and Chillas) feature significant precipitation increase in either all or at least one of the monsoon months. Such a precise response of monthly wetting and drying has been averaged out on seasonal to annual timescales, suggesting increase (decrease) for autumn and winter (spring and summer) but a mixed response for annual precipitation. 
Table 4. Trend for $T_{x}, T_{n}$ and DTR in ${ }^{\circ} \mathrm{C}$ (per unit time) at monthly to annual timescales over the period 1995-2012. Note: stations are given in top to bottom altitude order. Slopes significant at the $90 \%$ level are given in bold.

\begin{tabular}{|c|c|c|c|c|c|c|c|c|c|c|c|c|c|c|c|c|c|c|}
\hline Vars. & Stations & Jan & $\mathrm{Feb}$ & Mar & Apr & May & Jun & Jul & Aug & Sep & Oct & Nov & Dec & DJF & MAM & JJA & SON & Ann. \\
\hline \multirow[t]{18}{*}{$T_{x}$} & Khunjrab & 0.01 & -0.01 & 0.10 & 0.03 & 0.12 & -0.01 & -0.09 & 0.06 & -0.16 & 0.01 & 0.12 & 0.07 & 0.05 & 0.07 & -0.05 & 0.04 & 0.04 \\
\hline & Deosai & 0.02 & -0.05 & 0.07 & -0.01 & 0.06 & 0.01 & -0.19 & -0.01 & 0.00 & 0.02 & 0.06 & 0.05 & 0.08 & 0.06 & 0.03 & 0.02 & 0.06 \\
\hline & Shendure & -0.17 & -0.09 & 0.01 & -0.03 & -0.06 & -0.10 & -0.13 & -0.07 & -0.22 & -0.06 & 0.04 & -0.11 & -0.08 & -0.06 & -0.11 & -0.05 & -0.05 \\
\hline & Yasin & 0.00 & -0.03 & 0.13 & -0.02 & 0.10 & 0.03 & -0.16 & -0.08 & -0.35 & 0.12 & -0.02 & -0.10 & 0.03 & 0.08 & -0.06 & -0.01 & 0.05 \\
\hline & Rama & -0.06 & -0.07 & 0.02 & -0.11 & 0.14 & 0.04 & -0.11 & -0.09 & -0.29 & -0.10 & 0.01 & 0.00 & -0.04 & -0.04 & -0.07 & -0.07 & -0.08 \\
\hline & Hushe & -0.05 & -0.01 & 0.09 & 0.00 & 0.17 & -0.06 & -0.09 & 0.02 & -0.20 & -0.09 & 0.01 & 0.03 & 0.02 & 0.03 & -0.02 & -0.03 & -0.03 \\
\hline & Ushkore & -0.04 & -0.02 & 0.10 & 0.03 & 0.25 & -0.01 & -0.12 & -0.06 & -0.22 & -0.05 & 0.06 & -0.01 & 0.02 & 0.08 & -0.05 & -0.02 & -0.01 \\
\hline & Ziarat & 0.00 & -0.01 & 0.12 & -0.02 & 0.13 & 0.09 & -0.11 & -0.03 & -0.21 & -0.04 & 0.09 & 0.04 & 0.06 & 0.06 & -0.02 & -0.04 & 0.01 \\
\hline & Naltar & -0.04 & -0.04 & 0.10 & -0.03 & 0.10 & 0.03 & -0.12 & -0.03 & -0.19 & 0.03 & -0.01 & 0.01 & -0.02 & 0.07 & -0.03 & -0.05 & 0.00 \\
\hline & Rattu & -0.16 & -0.10 & 0.04 & -0.03 & 0.11 & 0.14 & -0.06 & -0.05 & -0.17 & -0.23 & 0.04 & -0.15 & -0.12 & -0.03 & 0.01 & -0.03 & -0.07 \\
\hline & Shigar & -0.04 & -0.08 & -0.02 & -0.08 & -0.38 & -0.15 & -0.08 & 0.03 & -0.01 & -0.09 & 0.11 & 0.01 & -0.02 & -0.09 & -0.09 & -0.02 & -0.02 \\
\hline & Skardu & 0.10 & 0.08 & 0.12 & 0.04 & 0.04 & -0.08 & -0.10 & 0.06 & -0.23 & -0.10 & -0.04 & -0.05 & -0.02 & 0.13 & -0.07 & -0.09 & -0.02 \\
\hline & Astore & 0.09 & 0.00 & 0.20 & 0.03 & 0.18 & 0.06 & -0.05 & -0.03 & -0.15 & -0.11 & 0.05 & 0.04 & 0.08 & 0.15 & -0.01 & -0.05 & 0.02 \\
\hline & Gupis & -0.05 & 0.03 & 0.27 & 0.11 & 0.20 & 0.01 & -0.09 & -0.13 & -0.09 & 0.12 & 0.12 & 0.03 & 0.11 & 0.20 & 0.03 & 0.03 & 0.07 \\
\hline & Dainyor & -0.04 & -0.08 & 0.23 & -0.02 & 0.15 & -0.19 & -0.18 & 0.01 & -0.15 & -0.04 & 0.10 & -0.07 & -0.06 & 0.14 & -0.08 & -0.01 & -0.02 \\
\hline & Gilgit & 0.09 & -0.07 & 0.12 & 0.03 & 0.15 & 0.02 & -0.15 & -0.08 & -0.31 & -0.07 & 0.07 & -0.05 & -0.04 & 0.06 & -0.05 & -0.08 & -0.05 \\
\hline & Bunji & 0.09 & -0.08 & 0.13 & 0.04 & 0.11 & 0.07 & -0.01 & 0.04 & -0.22 & -0.12 & -0.01 & -0.08 & 0.00 & 0.11 & 0.02 & -0.07 & -0.02 \\
\hline & Chillas & 0.09 & -0.03 & 0.16 & 0.01 & 0.13 & 0.01 & -0.15 & -0.06 & -0.24 & 0.00 & 0.03 & -0.06 & -0.05 & 0.08 & -0.07 & -0.05 & -0.06 \\
\hline \multirow[t]{18}{*}{$T_{n}$} & Khunjrab & 0.15 & 0.26 & 0.16 & 0.03 & 0.18 & -0.02 & -0.04 & 0.00 & 0.01 & 0.05 & 0.17 & 0.10 & 0.21 & 0.08 & -0.01 & 0.06 & 0.09 \\
\hline & Deosai & 0.02 & 0.09 & 0.21 & 0.00 & 0.01 & 0.00 & 0.03 & -0.02 & -0.08 & 0.03 & 0.09 & 0.00 & 0.06 & 0.10 & -0.02 & 0.05 & 0.10 \\
\hline & Shendure & 0.04 & -0.03 & 0.10 & 0.06 & 0.05 & 0.00 & -0.06 & 0.00 & -0.10 & -0.01 & 0.10 & 0.08 & 0.09 & 0.07 & -0.03 & 0.01 & 0.05 \\
\hline & Yasin & 0.09 & 0.07 & 0.12 & 0.02 & 0.10 & 0.01 & -0.11 & -0.05 & -0.21 & 0.10 & 0.04 & -0.08 & 0.06 & 0.11 & -0.04 & 0.03 & 0.08 \\
\hline & Rama & -0.08 & 0.10 & 0.05 & 0.02 & 0.06 & 0.01 & 0.00 & 0.01 & -0.09 & 0.00 & 0.11 & 0.07 & -0.02 & 0.03 & 0.03 & 0.02 & 0.02 \\
\hline & Hushe & 0.00 & 0.14 & 0.08 & 0.02 & 0.14 & -0.04 & -0.08 & 0.04 & -0.09 & -0.04 & 0.04 & 0.01 & 0.06 & 0.06 & -0.01 & 0.01 & 0.01 \\
\hline & Ushkore & -0.06 & 0.05 & 0.08 & 0.09 & 0.13 & 0.00 & -0.04 & -0.02 & -0.16 & -0.09 & 0.08 & 0.01 & 0.00 & 0.08 & 0.01 & -0.01 & 0.00 \\
\hline & Ziarat & 0.12 & 0.23 & 0.11 & 0.04 & 0.04 & 0.04 & -0.08 & 0.01 & -0.10 & -0.01 & 0.09 & 0.09 & 0.17 & 0.07 & 0.00 & 0.01 & 0.06 \\
\hline & Naltar & -0.01 & 0.08 & 0.10 & 0.02 & -0.01 & -0.03 & -0.10 & -0.01 & -0.07 & 0.00 & -0.03 & 0.00 & -0.07 & 0.10 & -0.03 & -0.01 & 0.04 \\
\hline & Rattu & -0.05 & 0.10 & -0.08 & -0.02 & 0.06 & 0.05 & -0.07 & 0.01 & -0.12 & -0.02 & 0.07 & 0.01 & 0.04 & -0.03 & 0.01 & -0.08 & -0.04 \\
\hline & Shigar & 0.03 & 0.02 & -0.01 & -0.03 & -0.21 & -0.09 & -0.07 & 0.05 & 0.07 & -0.11 & 0.05 & 0.04 & 0.01 & -0.02 & -0.06 & -0.01 & 0.01 \\
\hline & Skardu & -0.03 & 0.08 & -0.02 & -0.02 & -0.07 & -0.11 & -0.15 & -0.08 & -0.10 & -0.12 & -0.14 & -0.11 & -0.18 & -0.01 & -0.12 & -0.16 & -0.08 \\
\hline & Astore & 0.01 & 0.09 & 0.05 & 0.03 & -0.02 & 0.02 & -0.07 & 0.01 & -0.10 & -0.05 & 0.05 & -0.08 & 0.06 & 0.11 & -0.01 & -0.03 & -0.02 \\
\hline & Gupis & -0.15 & -0.03 & 0.19 & 0.11 & 0.09 & 0.03 & -0.04 & 0.04 & -0.07 & -0.03 & -0.12 & -0.14 & -0.11 & 0.14 & -0.04 & -0.09 & 0.01 \\
\hline & Dainyor & -0.13 & 0.01 & 0.13 & 0.01 & 0.11 & -0.04 & -0.17 & 0.03 & -0.06 & -0.02 & -0.06 & -0.05 & 0.01 & 0.07 & -0.03 & -0.04 & 0.01 \\
\hline & Gilgit & 0.03 & 0.10 & 0.06 & 0.04 & 0.04 & 0.05 & -0.01 & 0.26 & 0.30 & 0.05 & 0.09 & -0.01 & 0.08 & 0.07 & 0.06 & 0.19 & 0.08 \\
\hline & Bunji & 0.01 & 0.03 & 0.05 & 0.03 & 0.02 & 0.04 & -0.01 & 0.17 & 0.01 & 0.03 & 0.13 & 0.00 & 0.02 & 0.05 & 0.06 & 0.04 & 0.03 \\
\hline & Chillas & -0.09 & -0.18 & 0.01 & -0.07 & 0.02 & -0.05 & -0.11 & -0.08 & -0.21 & -0.10 & 0.00 & -0.06 & -0.15 & -0.05 & -0.07 & -0.11 & -0.07 \\
\hline \multirow[t]{18}{*}{ DTR } & Khunjrab & -0.10 & -0.25 & -0.30 & -0.19 & -0.24 & -0.08 & -0.13 & -0.11 & -0.11 & -0.04 & -0.03 & -0.05 & -0.17 & -0.18 & -0.04 & -0.04 & -0.08 \\
\hline & Deosai & 0.07 & -0.09 & 0.01 & 0.11 & -0.05 & 0.05 & 0.16 & 0.19 & 0.01 & 0.02 & -0.01 & 0.03 & 0.01 & 0.00 & 0.13 & 0.01 & 0.13 \\
\hline & Shendure & -0.06 & -0.09 & -0.26 & -0.29 & -0.17 & -0.08 & -0.03 & -0.05 & -0.09 & -0.07 & -0.05 & -0.24 & -0.12 & -0.20 & -0.10 & -0.06 & -0.15 \\
\hline & Yasin & -0.13 & -0.23 & -0.05 & -0.15 & -0.12 & -0.20 & -0.13 & -0.11 & -0.22 & -0.58 & -0.24 & -0.19 & -0.08 & -0.07 & -0.14 & -0.25 & -0.12 \\
\hline & Rama & -0.05 & -0.16 & -0.04 & -0.11 & -0.04 & -0.02 & -0.15 & -0.13 & -0.27 & -0.20 & -0.08 & -0.07 & -0.09 & -0.07 & -0.07 & -0.13 & -0.08 \\
\hline & Hushe & -0.08 & -0.17 & -0.01 & -0.05 & -0.02 & 0.00 & -0.03 & -0.02 & -0.07 & 0.00 & -0.03 & -0.01 & -0.10 & -0.01 & -0.02 & -0.03 & -0.04 \\
\hline & Ushkore & 0.00 & -0.06 & -0.02 & -0.08 & -0.01 & -0.05 & -0.01 & -0.02 & -0.08 & -0.01 & -0.02 & -0.03 & -0.03 & -0.02 & -0.03 & -0.03 & -0.03 \\
\hline & Ziarat & -0.09 & -0.26 & 0.02 & -0.02 & 0.01 & -0.01 & -0.05 & -0.01 & -0.10 & -0.03 & -0.03 & -0.12 & -0.13 & 0.03 & -0.02 & -0.05 & -0.06 \\
\hline & Naltar & -0.06 & -0.15 & 0.02 & -0.06 & 0.06 & -0.02 & -0.02 & -0.02 & -0.09 & -0.03 & -0.03 & -0.13 & -0.08 & 0.00 & -0.01 & -0.06 & -0.05 \\
\hline & Rattu & -0.10 & -0.16 & -0.04 & -0.10 & 0.02 & -0.04 & -0.09 & -0.11 & -0.18 & -0.16 & -0.18 & -0.15 & -0.12 & -0.01 & -0.04 & -0.10 & -0.05 \\
\hline & Shigar & 0.08 & 0.00 & -0.05 & 0.00 & 0.01 & 0.03 & -0.03 & -0.01 & -0.07 & 0.01 & -0.08 & 0.07 & 0.07 & 0.03 & -0.06 & 0.00 & -0.07 \\
\hline & Skardu & -0.04 & -0.14 & 0.06 & 0.01 & 0.13 & 0.06 & -0.01 & -0.02 & -0.21 & 0.04 & 0.03 & 0.14 & -0.07 & 0.07 & -0.01 & -0.01 & 0.00 \\
\hline & Astore & -0.02 & -0.13 & 0.13 & 0.00 & 0.05 & 0.00 & -0.03 & -0.07 & -0.08 & 0.03 & -0.03 & 0.04 & -0.09 & 0.06 & -0.02 & -0.05 & -0.01 \\
\hline & Gupis & 0.04 & 0.00 & 0.15 & -0.01 & 0.10 & -0.01 & -0.03 & -0.10 & -0.05 & 0.16 & 0.16 & 0.15 & 0.13 & 0.07 & -0.06 & 0.09 & 0.09 \\
\hline & Dainyor & -0.05 & -0.09 & 0.06 & -0.11 & -0.21 & -0.19 & -0.11 & -0.07 & -0.10 & -0.44 & -0.01 & -0.07 & -0.09 & -0.07 & -0.23 & -0.12 & -0.19 \\
\hline & Gilgit & -0.13 & -0.19 & 0.05 & -0.02 & 0.10 & -0.13 & -0.27 & -0.26 & -0.87 & -0.18 & -0.09 & -0.02 & -0.11 & -0.03 & -0.15 & -0.25 & -0.18 \\
\hline & Bunji & -0.04 & -0.14 & 0.05 & 0.03 & 0.04 & -0.01 & -0.03 & -0.04 & -0.27 & -0.03 & -0.16 & -0.10 & -0.07 & 0.06 & -0.01 & -0.14 & -0.05 \\
\hline & Chillas & 0.07 & 0.09 & 0.21 & 0.11 & 0.13 & 0.03 & -0.04 & 0.04 & 0.00 & 0.08 & 0.01 & 0.04 & 0.10 & 0.14 & 0.02 & 0.02 & 0.02 \\
\hline
\end{tabular}

Comparison of long-term trends at low-altitude stations (1961-2012) with their trends over recent period (1995-2012) suggests that the long-term spring drying, particularly of March and April, and wetting of September (the last monsoonal month) have recently intensified, while the long-term increasing summer precipitation has changed to decreasing (see Tables 5 and 6).

\subsubsection{Discharge}

From Fig. 3, we clearly show that snow and glacier melt regimes of the UIB can be differentiated from the maximum runoff production timing based on the median hydrographs of available gauges. Figure 3 suggests that Indus at Kharmong (UIB-East), Gilgit at Gilgit (Hindukush) and Astore at Doyian basins, which generally feature their peak runoffs in June/July, are primarily snow-fed, while the rest that feature peak runoff in August are mainly glacier-fed. 
Table 5. Same as Table 4. Here, slopes for $P$ are in $\mathrm{mm}$ and for $Q$ in $\mathrm{m}^{3} \mathrm{~s}^{-1}$. Hydrometric gauges are given in downstream order.

\begin{tabular}{|c|c|c|c|c|c|c|c|c|c|c|c|c|c|c|c|c|c|c|}
\hline Vars. & Stations & Jan & Feb & Mar & Apr & May & Jun & Jul & Aug & Sep & Oct & Nov & Dec & DJF & MAM & JJA & SON & Ann. \\
\hline \multirow[t]{18}{*}{$T_{\text {avg }}$} & Khunjrab & 0.13 & 0.09 & 0.13 & 0.05 & 0.19 & 0.00 & -0.06 & 0.06 & -0.13 & 0.05 & 0.17 & 0.10 & 0.15 & 0.09 & -0.03 & 0.06 & 0.06 \\
\hline & Deosai & 0.06 & 0.01 & 0.15 & 0.00 & 0.07 & 0.01 & -0.07 & 0.03 & -0.05 & 0.02 & 0.08 & 0.01 & 0.10 & 0.06 & 0.03 & 0.04 & 0.07 \\
\hline & Shendure & -0.05 & -0.05 & 0.05 & 0.02 & 0.02 & -0.05 & -0.10 & -0.05 & -0.15 & -0.04 & 0.06 & -0.03 & 0.01 & -0.04 & -0.05 & -0.02 & 0.01 \\
\hline & Yasin & 0.02 & 0.01 & 0.13 & 0.01 & 0.06 & 0.04 & -0.19 & -0.07 & -0.27 & 0.11 & 0.01 & -0.08 & 0.04 & 0.13 & -0.05 & 0.02 & 0.06 \\
\hline & Rama & -0.12 & 0.02 & 0.05 & -0.06 & 0.07 & 0.01 & -0.03 & -0.03 & -0.19 & -0.09 & 0.05 & 0.02 & 0.02 & 0.00 & 0.00 & -0.01 & -0.04 \\
\hline & Hushe & -0.03 & 0.05 & 0.06 & 0.02 & 0.14 & -0.05 & -0.07 & 0.02 & -0.13 & -0.07 & 0.03 & 0.04 & 0.01 & 0.06 & -0.01 & 0.00 & -0.01 \\
\hline & Ushkore & -0.07 & 0.00 & 0.08 & 0.05 & 0.21 & 0.00 & -0.03 & -0.03 & -0.17 & -0.09 & 0.06 & 0.01 & 0.04 & 0.09 & -0.01 & -0.02 & 0.01 \\
\hline & Ziarat & 0.04 & 0.11 & 0.10 & 0.00 & 0.09 & 0.06 & -0.09 & -0.03 & -0.15 & -0.03 & 0.09 & 0.03 & 0.08 & 0.07 & -0.02 & 0.00 & 0.05 \\
\hline & Naltar & -0.03 & 0.01 & 0.08 & -0.05 & -0.11 & -0.07 & -0.12 & -0.06 & -0.17 & 0.00 & -0.03 & 0.01 & -0.13 & 0.07 & -0.04 & -0.04 & 0.01 \\
\hline & Rattu & -0.11 & -0.01 & -0.05 & -0.04 & 0.09 & 0.10 & -0.04 & 0.00 & -0.18 & -0.07 & 0.04 & -0.10 & -0.06 & 0.03 & 0.00 & -0.05 & -0.05 \\
\hline & Shigar & 0.05 & -0.02 & 0.00 & -0.06 & -0.30 & -0.13 & -0.13 & 0.04 & 0.04 & -0.14 & 0.07 & 0.03 & 0.01 & -0.04 & -0.07 & -0.01 & 0.00 \\
\hline & Skardu & 0.02 & 0.11 & 0.07 & 0.01 & 0.02 & -0.10 & -0.15 & 0.04 & -0.17 & -0.11 & -0.06 & -0.07 & -0.11 & 0.06 & -0.12 & -0.12 & -0.07 \\
\hline & Astore & 0.10 & 0.03 & 0.12 & 0.01 & 0.13 & 0.03 & -0.05 & 0.00 & -0.14 & -0.09 & 0.03 & -0.01 & 0.05 & 0.13 & -0.02 & -0.03 & 0.01 \\
\hline & Gupis & -0.08 & -0.06 & 0.22 & 0.09 & 0.13 & 0.00 & -0.05 & -0.05 & -0.08 & 0.06 & 0.04 & -0.07 & 0.02 & 0.14 & 0.02 & -0.01 & 0.03 \\
\hline & Dainyor & -0.06 & -0.02 & 0.22 & -0.01 & 0.18 & -0.08 & -0.15 & 0.02 & -0.11 & -0.04 & 0.04 & -0.09 & -0.05 & 0.11 & -0.04 & -0.04 & 0.00 \\
\hline & Gilgit & 0.02 & 0.01 & 0.11 & 0.03 & 0.06 & 0.04 & -0.06 & 0.05 & -0.09 & 0.00 & 0.08 & 0.05 & 0.03 & 0.08 & -0.02 & 0.00 & 0.03 \\
\hline & Bunji & 0.06 & -0.02 & 0.06 & 0.02 & 0.05 & 0.02 & 0.00 & 0.09 & -0.07 & 0.03 & 0.06 & -0.06 & 0.03 & 0.08 & 0.06 & 0.00 & 0.01 \\
\hline & Chillas & -0.02 & -0.14 & 0.06 & -0.02 & 0.16 & -0.03 & -0.12 & -0.07 & -0.19 & -0.07 & 0.01 & -0.06 & -0.09 & 0.03 & -0.06 & -0.08 & -0.07 \\
\hline \multirow[t]{18}{*}{$P$} & Khunjrab & 3.64 & 2.59 & -2.21 & -1.55 & -1.47 & 0.10 & 0.35 & 0.80 & 1.82 & -1.04 & 0.93 & 2.34 & 8.86 & -9.09 & -1.74 & 1.65 & 6.14 \\
\hline & Deosai & 0.07 & 1.28 & -1.42 & -0.66 & -1.27 & -0.89 & -0.40 & -1.00 & -0.77 & -0.42 & -0.81 & -0.32 & 1.40 & -4.50 & 0.00 & -1.99 & -7.87 \\
\hline & Shendure & 1.54 & 2.75 & 1.35 & 2.13 & 0.60 & 2.12 & 1.83 & 1.38 & 1.45 & 1.24 & 1.40 & 1.20 & 5.71 & 4.50 & 4.82 & 3.58 & 29.53 \\
\hline & Yasin & 1.33 & 1.86 & 0.59 & 0.25 & 1.22 & -0.50 & 1.45 & 0.02 & 0.92 & -0.21 & 0.06 & 2.74 & 6.09 & 0.60 & 1.32 & 0.26 & 11.70 \\
\hline & Rama & 0.77 & 0.00 & -6.50 & -8.55 & -4.52 & -2.16 & -2.35 & -1.89 & -1.44 & -2.05 & -3.74 & -2.03 & 7.00 & -25.44 & -8.41 & -14.60 & -43.92 \\
\hline & Hushe & 0.65 & 0.24 & -1.23 & -0.30 & -1.97 & -1.21 & -1.71 & -0.60 & 0.73 & -0.64 & 0.11 & 0.72 & 3.47 & -4.51 & -4.28 & 0.70 & -5.54 \\
\hline & Ushkore & 0.56 & -0.59 & -2.33 & -1.02 & -1.97 & -0.93 & 0.00 & -0.09 & 1.01 & -0.61 & -0.48 & 0.09 & -0.13 & -4.57 & -1.54 & -0.42 & -3.83 \\
\hline & Ziarat & -0.91 & -0.56 & -4.18 & -5.28 & -1.83 & 0.25 & -0.67 & -0.18 & 1.20 & -0.58 & -0.43 & -0.61 & -3.59 & -9.10 & -1.71 & -0.21 & -16.32 \\
\hline & Naltar & 3.75 & 8.41 & -4.49 & -0.36 & -2.75 & -2.17 & 0.43 & -2.33 & 1.32 & -0.36 & -0.70 & 1.35 & 19.43 & -8.39 & -0.99 & 2.42 & -0.28 \\
\hline & Rattu & 1.36 & 2.13 & 0.08 & 0.36 & 0.26 & 0.53 & 0.91 & 0.75 & 0.95 & 0.84 & 0.69 & 1.53 & 4.43 & 1.23 & 1.81 & 2.36 & 10.64 \\
\hline & Shigar & -0.24 & -0.89 & -1.07 & -2.62 & -2.05 & -0.33 & 1.75 & 0.80 & 2.40 & 1.13 & 0.18 & 1.49 & -1.67 & -8.36 & 0.78 & 3.08 & -7.04 \\
\hline & Skardu & -0.64 & 1.62 & 0.60 & 0.19 & -0.74 & -0.47 & -0.07 & -0.44 & 0.46 & 0.00 & 0.00 & 0.20 & 0.41 & 0.89 & -1.26 & 0.49 & 1.29 \\
\hline & Astore & 0.00 & 0.41 & 0.12 & -1.41 & -0.48 & -0.16 & -0.08 & -0.29 & 0.57 & 0.00 & 0.00 & 0.29 & 1.50 & -1.36 & -1.63 & 0.34 & -0.16 \\
\hline & Gupis & 0.65 & 0.97 & 0.81 & 0.38 & -0.06 & -1.33 & -1.07 & -0.49 & 0.06 & 0.35 & 0.26 & 0.89 & 2.81 & 0.29 & -3.49 & 0.43 & 4.46 \\
\hline & Dainyor & -0.21 & 0.42 & 0.51 & 0.55 & 0.67 & 1.24 & 0.91 & -0.71 & -0.39 & 0.00 & 0.00 & 0.00 & 1.68 & 1.81 & 3.09 & -0.34 & 6.69 \\
\hline & Gilgit & 0.98 & 0.45 & -1.94 & -1.34 & -1.57 & -0.73 & 0.29 & -3.99 & 0.32 & 0.00 & 0.00 & 0.30 & 0.00 & -9.39 & -9.60 & -0.92 & -20.31 \\
\hline & Bunji & 0.01 & -0.10 & -1.06 & -2.34 & 0.17 & 0.20 & -0.34 & -0.22 & 0.56 & -0.01 & 0.00 & 0.11 & -0.47 & -2.68 & -0.51 & 0.06 & 0.09 \\
\hline & Chillas & 0.00 & 0.13 & -0.14 & -1.56 & 0.16 & 0.29 & -0.51 & 0.13 & 1.37 & -0.10 & 0.00 & 0.07 & 0.22 & -0.81 & -0.80 & 1.86 & 0.53 \\
\hline \multirow[t]{16}{*}{$Q$} & UIB-East & -0.80 & 0.00 & 0.04 & 0.11 & -4.19 & 2.00 & -1.65 & 6.70 & -4.74 & -5.45 & -2.46 & -1.37 & -0.75 & -2.64 & -2.62 & -0.86 & -1.73 \\
\hline & Eastern Kara. & 0.06 & 0.08 & -0.10 & 0.00 & 1.96 & 0.96 & -22.97 & 0.92 & -8.84 & -1.06 & 0.50 & -0.09 & 0.29 & 0.67 & 0.30 & -4.41 & -0.95 \\
\hline & Central Kara. & 0.96 & 1.28 & 1.56 & -0.84 & 3.74 & -8.94 & -37.93 & -9.08 & -5.98 & 0.71 & 2.50 & 2.76 & 1.13 & 1.13 & -21.61 & 1.10 & -1.56 \\
\hline & Kachura & 0.33 & 1.39 & 1.06 & -0.33 & -2.08 & -22.50 & -50.04 & -16.74 & -4.25 & -2.18 & 0.59 & 2.64 & 0.46 & -0.81 & -18.90 & -2.63 & -4.97 \\
\hline & UIB-Central & 2.19 & 1.81 & 2.02 & -0.84 & 6.89 & -18.08 & -43.79 & -20.20 & -4.88 & 1.05 & 4.38 & 2.34 & 2.00 & 1.79 & -18.34 & 2.01 & -2.47 \\
\hline & Western-Kara. & 1.20 & 1.00 & 1.50 & 2.00 & 0.59 & 12.09 & -4.53 & -4.09 & 6.40 & 3.50 & 3.82 & 2.03 & 1.88 & 1.00 & -1.64 & 5.43 & 2.50 \\
\hline & Karakoram & 1.88 & 2.00 & 1.33 & 1.00 & -5.82 & -7.80 & -64.97 & -37.17 & -9.48 & 0.60 & 8.97 & 5.97 & 1.65 & 0.11 & -24.43 & 5.64 & -3.90 \\
\hline & Hindukush & 0.87 & 0.26 & 0.15 & 1.27 & 2.05 & 3.49 & -6.61 & 14.02 & $\mathbf{7 . 0 3}$ & 2.17 & 1.82 & 1.06 & 0.75 & 1.00 & 3.94 & 4.44 & 4.00 \\
\hline & UIB-WU & 1.24 & 1.02 & 1.39 & 2.38 & 16.85 & 12.38 & -25.48 & -15.50 & -1.28 & 0.69 & 0.98 & 0.52 & 0.55 & 7.76 & -3.68 & 0.45 & -1.25 \\
\hline & Astore & 0.05 & 0.00 & 0.22 & 0.50 & 7.65 & 4.26 & -3.01 & 5.00 & -1.00 & -1.11 & -0.67 & 0.00 & 0.00 & 2.20 & 1.97 & -0.89 & 2.16 \\
\hline & Partab Bridge & 1.00 & -0.13 & 3.60 & 8.80 & 63.22 & -34.86 & -39.86 & -67.33 & 29.65 & 0.69 & 8.89 & 15.12 & 8.40 & 36.29 & -67.00 & 9.81 & -12.40 \\
\hline & UIB-WL & 1.88 & 0.41 & 6.39 & -0.52 & 41.58 & $\mathbf{5 9 . 5 0}$ & 28.19 & 81.58 & 30.99 & 16.18 & 5.17 & 2.33 & 1.92 & 19.90 & 65.53 & 16.02 & 25.44 \\
\hline & UIB-WL-Partab & -3.00 & 0.80 & -4.38 & -0.82 & 87.89 & 51.53 & 9.00 & 17.67 & 2.71 & -12.24 & 1.40 & -6.00 & -3.74 & 28.32 & 47.93 & -3.00 & 18.94 \\
\hline & UIB-West & 2.45 & 1.37 & 5.43 & 2.42 & 61.35 & 54.89 & 0.21 & 42.93 & 28.24 & 13.68 & 5.87 & 1.38 & 2.00 & 23.43 & 44.18 & 17.71 & 22.17 \\
\hline & Himalaya & 0.30 & -0.32 & 4.10 & 0.91 & 43.99 & 62.23 & 12.43 & 83.33 & 22.43 & 9.97 & 2.32 & 0.23 & 1.17 & 26.64 & $\mathbf{5 7 . 8 8}$ & 7.75 & 24.66 \\
\hline & UIB & 1.82 & 5.09 & 5.37 & -2.50 & 11.35 & 14.67 & -46.60 & 41.71 & 35.22 & 10.17 & 5.29 & 0.75 & 1.91 & 15.72 & -1.40 & 19.35 & 4.25 \\
\hline
\end{tabular}

Over the 1995-2012 period, the discharge change pattern seems to be more consistent with tendencies in temperature than in precipitation record. Most of the hydrometric stations feature increasing discharge during October-June (dominant during May-June) but decreasing discharge during July, which is significant for five high-altitude/latitude glacierfed subregions (Karakoram, Shigar, Shyok, UIB-Central and Indus at Kachura), mainly owing to a drop in July temperatures (Table 5). There is a mixed response for August and September months; however, significant trends suggest an increasing discharge from two subregions (Hindukush and UIB-West-lower) in August and from four subregions (Hindukush, western Karakoram, UIB-West-lower and UIBWest) in September.

Despite dominant September cooling, discharge drops mainly during July, suggesting it to be the month of effec- tive cooling. Discharge in July is also decreasing for the whole UIB, though such a trend is not significant. During winter, spring and autumn, discharge at most sites features an increasing trend, while during summer and on an annual timescale there is a mixed response.

Long-term discharge is generally increasing from November to May (Table 6), where such an increase is higher in magnitude and mostly significant in May. There is a mixed response for June-October. Consistently on a coarser temporal scale, winter discharge is increasing while a mixed response is observed for other seasons and on an annual timescale. While comparing the long-term trends with those assessed over 1995-2012 period, we note prominent shifts in the sign of trends for the seasonal transitional month of June and within the high-flow period of July-September. Such shifts may be attributed to recent higher summer cool- 
Table 6. Long-term trends (1961-2012) in $T_{x}, T_{n}, T_{\text {avg }}$, DTR and $P$ at monthly to annual timescales in respective units as given in Tables 4 and 5. Note: "Kara" refers to Karakoram.

\begin{tabular}{|c|c|c|c|c|c|c|c|c|c|c|c|c|c|c|c|c|c|c|}
\hline Vars. & $\begin{array}{l}\text { Stations/ } \\
\text { subregions }\end{array}$ & Jan & Feb & Mar & Apr & May & Jun & Jul & Aug & Sep & Oct & Nov & Dec & DJF & MAM & JJA & SON & Ann. \\
\hline \multirow[t]{6}{*}{$T_{x}$} & Skardu & 0.07 & 0.06 & 0.06 & 0.05 & 0.07 & 0.02 & 0.01 & 0.00 & 0.02 & 0.03 & 0.06 & 0.06 & 0.05 & 0.07 & 0.01 & 0.04 & 0.04 \\
\hline & Astore & 0.02 & 0.01 & 0.06 & 0.04 & 0.05 & -0.01 & -0.01 & -0.02 & 0.00 & 0.02 & 0.03 & 0.04 & 0.02 & 0.06 & -0.01 & 0.02 & 0.02 \\
\hline & Gupis & 0.02 & 0.02 & 0.03 & 0.04 & 0.06 & -0.02 & -0.02 & -0.03 & -0.01 & 0.04 & 0.04 & 0.06 & 0.04 & 0.04 & -0.02 & 0.03 & 0.02 \\
\hline & Gilgit & 0.04 & 0.03 & 0.04 & 0.05 & 0.06 & -0.01 & -0.01 & -0.02 & -0.01 & 0.02 & 0.05 & 0.05 & 0.04 & 0.04 & -0.01 & 0.02 & 0.02 \\
\hline & Bunji & 0.02 & 0.01 & 0.04 & 0.00 & 0.01 & -0.06 & -0.05 & -0.05 & -0.04 & -0.04 & 0.03 & 0.02 & 0.02 & 0.02 & -0.05 & -0.02 & 0.00 \\
\hline & Chillas & -0.01 & -0.01 & 0.03 & 0.01 & 0.02 & -0.05 & -0.02 & -0.02 & -0.02 & 0.00 & 0.00 & 0.01 & 0.00 & 0.02 & -0.03 & 0.00 & 0.00 \\
\hline \multirow[t]{6}{*}{$T_{n}$} & Skardu & 0.00 & 0.02 & 0.00 & -0.01 & -0.01 & -0.04 & -0.04 & -0.04 & -0.04 & -0.05 & -0.02 & 0.01 & 0.01 & 0.00 & -0.04 & -0.04 & -0.02 \\
\hline & Astore & 0.02 & 0.01 & 0.03 & 0.03 & 0.04 & 0.00 & -0.02 & -0.02 & -0.01 & 0.00 & 0.02 & 0.01 & 0.01 & 0.04 & -0.01 & 0.01 & 0.01 \\
\hline & Gupis & -0.04 & -0.02 & -0.01 & -0.03 & -0.01 & -0.07 & -0.06 & -0.07 & -0.05 & -0.03 & -0.03 & -0.01 & -0.03 & -0.02 & -0.07 & -0.05 & -0.04 \\
\hline & Gilgit & 0.00 & 0.03 & 0.00 & -0.01 & 0.01 & -0.02 & -0.05 & -0.03 & -0.01 & -0.02 & -0.01 & 0.01 & 0.01 & 0.00 & -0.03 & -0.02 & -0.01 \\
\hline & Bunji & 0.01 & 0.01 & 0.03 & 0.00 & 0.00 & -0.03 & -0.04 & -0.03 & -0.03 & -0.03 & 0.00 & 0.01 & -0.01 & 0.01 & -0.04 & -0.04 & 0.00 \\
\hline & Chillas & 0.04 & 0.02 & 0.01 & 0.01 & 0.03 & -0.02 & -0.01 & -0.03 & -0.02 & 0.00 & 0.03 & 0.04 & 0.03 & 0.02 & -0.02 & 0.00 & 0.01 \\
\hline \multirow[t]{6}{*}{$T_{\text {avg }}$} & Skardu & 0.03 & 0.04 & 0.03 & 0.02 & 0.03 & -0.01 & -0.02 & -0.02 & -0.01 & 0.00 & 0.02 & 0.03 & 0.03 & 0.03 & -0.02 & 0.00 & 0.01 \\
\hline & Astore & 0.02 & 0.01 & 0.04 & 0.04 & 0.05 & 0.00 & -0.01 & -0.02 & 0.00 & 0.01 & 0.03 & 0.02 & 0.01 & 0.05 & -0.01 & 0.02 & 0.01 \\
\hline & Gupis & 0.00 & 0.00 & 0.00 & 0.01 & 0.03 & -0.04 & -0.05 & -0.05 & -0.03 & 0.00 & 0.01 & 0.02 & 0.00 & 0.01 & -0.04 & -0.01 & -0.01 \\
\hline & Gilgit & 0.02 & 0.03 & 0.02 & 0.02 & 0.04 & -0.02 & -0.03 & -0.03 & -0.02 & -0.01 & 0.03 & 0.03 & 0.03 & 0.02 & -0.03 & 0.00 & 0.00 \\
\hline & Bunji & 0.00 & 0.01 & 0.02 & -0.01 & -0.01 & -0.04 & -0.05 & -0.04 & -0.05 & -0.04 & 0.00 & 0.01 & 0.01 & 0.01 & -0.04 & -0.03 & 0.00 \\
\hline & Chillas & 0.02 & 0.00 & 0.01 & 0.01 & 0.03 & -0.03 & -0.02 & -0.02 & -0.02 & 0.00 & 0.02 & 0.02 & 0.01 & 0.02 & -0.03 & 0.00 & 0.00 \\
\hline \multirow[t]{6}{*}{ DTR } & Skardu & 0.06 & 0.02 & 0.05 & 0.07 & 0.09 & 0.05 & 0.06 & 0.03 & 0.06 & 0.09 & 0.09 & 0.05 & 0.05 & 0.07 & 0.05 & 0.09 & 0.06 \\
\hline & Astore & 0.04 & 0.00 & 0.01 & 0.02 & 0.02 & -0.02 & 0.01 & 0.02 & 0.01 & 0.02 & 0.02 & 0.01 & 0.02 & 0.01 & 0.00 & 0.02 & 0.02 \\
\hline & Gupis & 0.08 & 0.06 & 0.05 & 0.07 & 0.09 & 0.06 & 0.06 & 0.04 & 0.07 & 0.10 & 0.09 & 0.08 & 0.09 & 0.06 & 0.05 & 0.08 & 0.07 \\
\hline & Gilgit & 0.04 & 0.02 & 0.04 & 0.07 & 0.06 & 0.00 & 0.05 & 0.04 & 0.05 & 0.05 & 0.07 & 0.05 & 0.04 & 0.04 & 0.03 & 0.06 & 0.04 \\
\hline & Bunji & 0.04 & 0.01 & 0.03 & 0.01 & 0.03 & 0.00 & 0.00 & -0.01 & 0.03 & 0.02 & 0.06 & 0.04 & 0.04 & 0.02 & 0.00 & 0.03 & 0.02 \\
\hline & Chillas & -0.04 & -0.02 & 0.00 & 0.00 & 0.00 & -0.03 & -0.01 & 0.01 & 0.01 & -0.01 & -0.02 & -0.03 & -0.03 & 0.00 & -0.01 & -0.01 & -0.02 \\
\hline \multirow[t]{6}{*}{$P$} & Skardu & 0.30 & 0.32 & 0.16 & 0.16 & -0.02 & 0.08 & 0.06 & 0.19 & 0.07 & 0.00 & 0.00 & 0.15 & 0.98 & 0.45 & 0.29 & 0.12 & 1.76 \\
\hline & Astore & 0.00 & -0.28 & -0.78 & -0.51 & -0.25 & 0.27 & 0.19 & 0.06 & 0.02 & -0.05 & 0.02 & -0.08 & 0.24 & -1.31 & 0.45 & 0.06 & -1.33 \\
\hline & Gupis & 0.08 & 0.04 & 0.28 & 0.30 & -0.08 & 0.00 & 0.24 & 0.18 & 0.00 & 0.00 & 0.00 & 0.00 & 0.11 & 0.20 & 0.32 & -0.09 & 2.00 \\
\hline & Gilgit & 0.00 & 0.00 & -0.02 & 0.05 & -0.05 & 0.23 & 0.01 & 0.01 & 0.03 & 0.00 & 0.00 & 0.00 & 0.02 & -0.44 & 0.28 & 0.10 & 0.38 \\
\hline & Bunji & 0.00 & -0.06 & -0.14 & 0.02 & -0.17 & 0.09 & 0.05 & 0.12 & 0.11 & -0.03 & 0.00 & 0.00 & 0.13 & -0.59 & 0.36 & 0.09 & 0.21 \\
\hline & Chillas & 0.00 & 0.03 & -0.12 & 0.00 & -0.01 & 0.10 & 0.07 & 0.07 & 0.07 & -0.02 & 0.00 & 0.00 & 0.25 & -0.12 & 0.51 & 0.03 & 0.70 \\
\hline \multirow[t]{16}{*}{$Q$} & UIB-East & 0.58 & 0.89 & 1.18 & 0.80 & 0.08 & -12.94 & -21.37 & -10.53 & -1.42 & -0.18 & 0.06 & 0.16 & 0.55 & 1.10 & -14.86 & -0.57 & -1.59 \\
\hline & Eastern Kara. & 0.00 & 0.00 & -0.04 & -0.08 & 1.79 & 6.46 & 5.17 & 6.81 & 4.34 & 1.31 & 0.24 & 0.00 & 0.07 & 0.41 & 7.08 & 2.05 & 2.43 \\
\hline & Central Kara. & 0.32 & -0.07 & -0.51 & -0.67 & 6.13 & 3.85 & -1.22 & 6.30 & -7.40 & -4.08 & -1.36 & -0.29 & -0.35 & 1.75 & 6.22 & -2.80 & 0.31 \\
\hline & Kachura & 1.04 & 1.40 & 1.19 & 0.43 & 6.06 & 12.88 & 14.75 & 19.45 & 14.27 & 3.69 & 1.14 & 1.13 & 1.12 & 2.67 & 19.20 & 6.12 & 7.19 \\
\hline & UIB-Central & 0.35 & 0.21 & -0.19 & -0.43 & 9.99 & 20.49 & 13.74 & 20.73 & -4.95 & -2.15 & -0.80 & -0.29 & -0.30 & 2.76 & 17.69 & -2.84 & 3.30 \\
\hline & Western Kara. & 0.04 & 0.00 & 0.00 & 0.00 & 0.29 & -3.75 & -12.69 & -13.75 & -2.14 & -0.24 & 0.18 & 0.20 & 0.13 & 0.24 & -10.23 & -0.59 & -2.55 \\
\hline & Karakoram & 0.28 & -0.20 & -0.60 & 0.33 & 9.67 & 24.33 & 8.29 & 8.13 & -7.57 & -2.18 & -0.59 & 0.63 & -0.15 & 4.17 & 24.39 & -4.36 & 6.44 \\
\hline & Hindukush & 0.00 & 0.05 & 0.04 & 0.19 & 3.31 & -1.00 & -0.85 & 0.11 & 0.64 & 0.23 & 0.15 & 0.13 & 0.04 & 1.25 & 0.24 & 0.31 & 0.48 \\
\hline & UIB-WU & 0.58 & 0.60 & 0.33 & 0.51 & 3.55 & -1.86 & -12.74 & -12.50 & 0.68 & 1.48 & 1.02 & 0.71 & 0.48 & 1.30 & -6.83 & 1.22 & -0.95 \\
\hline & Astore & 0.28 & 0.24 & 0.32 & 0.97 & 3.52 & 1.29 & -0.62 & 0.54 & 0.16 & 0.28 & 0.32 & 0.23 & 0.31 & 1.63 & 0.43 & 0.28 & 0.76 \\
\hline & Partab Bridge & 1.01 & 0.49 & 0.44 & 1.93 & 18.03 & 13.07 & 12.89 & -8.37 & 9.74 & 3.84 & 2.61 & 1.63 & 1.74 & 6.84 & 7.05 & 4.93 & 4.72 \\
\hline & UIB-WL & 1.94 & 1.96 & 3.49 & 0.17 & 2.89 & -12.90 & -25.95 & -12.06 & -1.35 & 1.57 & 1.94 & 2.35 & 1.92 & 1.93 & -13.82 & 0.48 & -2.63 \\
\hline & UIB-WL-Partab & 1.58 & 1.87 & 2.11 & -0.82 & -0.30 & -22.26 & -16.35 & -17.07 & 0.02 & -2.20 & 0.23 & 1.18 & 1.32 & 0.34 & -22.10 & -0.99 & -5.40 \\
\hline & UIB-West & 2.02 & 2.01 & 2.73 & 1.12 & 8.00 & -19.88 & -32.88 & -23.24 & -5.13 & 1.95 & 2.59 & 2.40 & 2.18 & 3.99 & -25.21 & 0.93 & -4.03 \\
\hline & Himalaya & 3.23 & 3.91 & 4.73 & 2.33 & -0.33 & -32.29 & -69.33 & -17.55 & -4.61 & -0.05 & 3.40 & 2.05 & 3.37 & 6.86 & -40.09 & -0.72 & -6.13 \\
\hline & UIB & 3.00 & 3.33 & 3.53 & 0.62 & 12.97 & -8.84 & -13.31 & -3.24 & 8.19 & 4.03 & 3.92 & 3.04 & 3.04 & 5.00 & -6.15 & 5.14 & 2.23 \\
\hline
\end{tabular}

ing accompanied by enhanced monsoonal precipitation. For instance, long-term July discharge is increasing for eastern, central and the whole of Karakoram, UIB-Central, Indus at Kachura, Indus at Partab Bridge and Astore but decreasing for other subregions. In contrast, trends over the recent two decades feature opposite signs, except for Astore, UIB-Westupper and its subregions.

\subsection{Field significance and physical attribution}

We present the mean of positive and negative field-significant trends from each region (if both exist) in order to present the dominant signal (Table 7). Results show clear fieldsignificant warming for most of the regions in March followed by August. Similarly, field-significant drying is found in March over all regions except Karakoram and UIBCentral. Similarly to local trends, we find field-significant cooling over all subregions in July, September and October, which, on a seasonal timescale, dominates in autumn followed by summer. Note that most of the climatic trends are not field-significant for the transitional (or pre-monsoonal) period of April-June.

We find a general trend of narrowing DTR, which is associated with either warming of $T_{n}$ against cooling of $T_{x}$ or relatively lower cooling in $T_{n}$ than in $T_{x}$. Field-significant drying of the lower latitudinal generally snow-fed subregions (Astore, Himalaya, UIB-West-lower) is also observed particularly during March-September and thus for spring and summer and on an annual timescale. On the other hand, wetting (drying) of winter and autumn (spring and summer) is observed for the Hindukush, UIB-West, UIB-West-upper and whole UIB. For the western Karakoram, increasing precipitation is observed only for winter. For the whole Karakoram and UIB-Central, a field-significant increasing precipitation 
Table 7. Field-significant climatic trends for 10 subregions along with their discharge $(Q)$ trends at monthly to annual timescales over the period 1995-2012. Bold $Q$ values indicate significant trends at the $90 \%$ level.

\begin{tabular}{|c|c|c|c|c|c|c|c|c|c|c|c|c|c|c|c|c|c|c|}
\hline $\begin{array}{l}\text { Sub- } \\
\text { regions }\end{array}$ & Vars. & Jan & $\mathrm{Feb}$ & Mar & Apr & May & Jun & Jul & Aug & Sep & Oct & Nov & Dec & DJF & MAM & JJA & SON & Ann. \\
\hline \multirow[t]{6}{*}{ Astore } & $T_{x}$ & -0.17 & & & & & & & & & -0.21 & & -0.42 & -0.16 & & & & -0.06 \\
\hline & $T_{n}$ & & & & & & & -0.10 & & & -0.10 & & -0.12 & & & & -0.10 & \\
\hline & $T_{\text {avg }}$ & -0.15 & & & & & & -0.13 & & & -0.21 & & & & & & & -0.05 \\
\hline & DTR & & -0.22 & & & & & & & -0.13 & & & -0.17 & -0.07 & & & -0.06 & -0.08 \\
\hline & $P$ & & & -3.73 & -7.50 & -4.60 & -2.18 & -1.90 & -1.80 & -2.11 & & & & & -19.25 & -6.02 & -18.93 & -38.01 \\
\hline & $Q$ & 0.05 & 0.00 & 0.22 & 0.50 & 7.65 & 4.26 & -3.01 & 5.00 & -1.00 & -1.11 & -0.67 & 0.00 & 0.00 & 2.20 & 1.97 & -0.89 & 2.16 \\
\hline \multirow[t]{6}{*}{ Hindukush } & $T_{x}$ & & -0.11 & 0.23 & & & & -0.19 & & -0.29 & & & -0.18 & & & & -0.12 & -0.09 \\
\hline & $T_{n}$ & & & & & & & & 0.25 & 0.24 & & -0.18 & -0.24 & & & 0.09 & 0.10 & \\
\hline & $T_{\mathrm{avg}}$ & & & 0.18 & & & & -0.11 & 0.08 & -0.25 & & & -0.13 & & & & -0.10 & \\
\hline & DTR & -0.21 & & -0.11 & -0.18 & -0.25 & -0.28 & -0.19 & -0.36 & -0.40 & -0.52 & -0.38 & & 0.03 & -0.16 & -0.18 & -0.33 & -0.20 \\
\hline & $P$ & 1.30 & & -1.94 & & & & 1.00 & & 1.05 & 0.31 & & 1.31 & 4.73 & -10.19 & -9.80 & 2.39 & \\
\hline & $Q$ & 0.87 & 0.26 & 0.15 & 1.27 & 2.05 & 3.49 & -6.61 & 14.02 & 7.03 & 2.17 & 1.82 & 1.06 & 0.75 & 1.00 & 3.94 & 4.44 & 4.00 \\
\hline \multirow[t]{6}{*}{ Himalaya } & $T_{x}$ & -0.17 & -0.10 & & & & & -0.22 & & -0.21 & -0.19 & & -0.28 & -0.16 & & -0.07 & -0.12 & -0.06 \\
\hline & $T_{n}$ & & -0.23 & 0.26 & & & -0.14 & -0.15 & 0.18 & & -0.16 & -0.18 & -0.14 & -0.18 & & -0.13 & -0.14 & 0.02 \\
\hline & $T_{\text {avg }}$ & -0.15 & & 0.25 & & & & -0.18 & 0.17 & -0.18 & -0.18 & -0.09 & -0.08 & -0.11 & & -0.10 & -0.13 & -0.07 \\
\hline & DTR & -0.02 & -0.20 & 0.18 & -0.18 & & & -0.13 & -0.18 & -0.36 & -0.25 & & & -0.12 & & -0.08 & -0.19 & -0.09 \\
\hline & $P$ & & & -2.29 & -5.71 & -4.60 & -2.18 & -1.90 & -1.80 & -2.11 & & & 0.42 & & -12.15 & -6.02 & -18.93 & -38.01 \\
\hline & $Q$ & 0.30 & -0.32 & 4.10 & 0.91 & 43.99 & 62.23 & 12.43 & 83.33 & 22.43 & 9.97 & 2.32 & 0.23 & 1.17 & 26.64 & $\mathbf{5 7 . 8 8}$ & 7.75 & 24.66 \\
\hline \multirow{6}{*}{$\begin{array}{l}\text { West } \\
\text { Karakoram }\end{array}$} & $T_{x}$ & & & 0.23 & & & & -0.18 & & -0.17 & -0.16 & & & -0.06 & & & & \\
\hline & $T_{n}$ & & 0.22 & 0.13 & & & & -0.13 & & & & & & 0.17 & & & & 0.05 \\
\hline & $T_{\text {avg }}$ & -0.15 & & 0.22 & -0.09 & & & -0.14 & & -0.15 & & & & & & & & \\
\hline & DTR & & -0.22 & & & & & & & -0.13 & & & -0.17 & -0.07 & & & -0.06 & -0.08 \\
\hline & $P$ & & & & & 1.17 & 1.09 & & & & & & 3.81 & 9.08 & & & & \\
\hline & $Q$ & 1.20 & 1.00 & 1.50 & 2.00 & 0.59 & 12.09 & -4.53 & -4.09 & 6.40 & 3.50 & 3.82 & 2.03 & 1.88 & 1.00 & -1.64 & 5.43 & 2.50 \\
\hline \multirow[t]{6}{*}{ Karakoram } & $T_{x}$ & & -0.11 & 0.23 & & & & -0.18 & & -0.22 & -0.16 & & & -0.06 & & & -0.12 & -0.06 \\
\hline & $T_{n}$ & & -0.11 & 0.23 & & & & -0.18 & & -0.22 & -0.16 & & & -0.06 & & & -0.12 & -0.06 \\
\hline & $T_{\text {avg }}$ & & 0.22 & 0.13 & & & -0.14 & -0.14 & 0.25 & 0.46 & -0.16 & -0.18 & -0.16 & 0.17 & & -0.08 & 0.06 & -0.05 \\
\hline & DTR & -0.15 & & 0.22 & -0.09 & & & -0.15 & 0.08 & -0.16 & -0.12 & -0.09 & & & & -0.13 & -0.14 & -0.08 \\
\hline & $P$ & & 2.95 & 1.97 & & 1.17 & 1.72 & & 1.58 & 2.15 & 1.43 & 2.40 & 2.69 & 6.39 & & 5.39 & 5.76 & 45.07 \\
\hline & $Q$ & 1.88 & 2.00 & 1.33 & 1.00 & -5.82 & -7.80 & -64.97 & -37.17 & -9.48 & 0.60 & 8.97 & 5.97 & 1.65 & 0.11 & -24.43 & 5.64 & -3.90 \\
\hline \multirow[t]{6}{*}{ UIB-Central } & $T_{x}$ & & & & & & & -0.26 & & -0.20 & -0.16 & & & & & & -0.12 & \\
\hline & $T_{n}$ & & & 0.26 & & & -0.14 & -0.20 & & & -0.16 & -0.18 & -0.16 & & & -0.17 & -0.18 & 0.02 \\
\hline & $T_{\text {avg }}$ & & & 0.25 & & & & -0.20 & & -0.18 & -0.15 & -0.09 & & & & -0.13 & -0.14 & -0.08 \\
\hline & DTR & 0.13 & & & & & & & & & & 0.09 & & & & & & \\
\hline & $P$ & & 2.95 & 1.97 & & & 2.35 & & 1.58 & 2.15 & 1.43 & 2.40 & 1.57 & 5.99 & & 5.39 & 5.76 & 45.07 \\
\hline & $Q$ & 2.19 & 1.81 & 2.02 & -0.84 & 6.89 & -18.08 & -43.79 & -20.20 & -4.88 & 1.05 & 4.38 & 2.34 & 2.00 & 1.79 & -18.34 & 2.01 & -2.47 \\
\hline \multirow[t]{6}{*}{ UIB } & $T_{x}$ & -0.14 & -0.11 & 0.40 & & & & -0.20 & & -0.22 & -0.20 & & -0.25 & & & -0.09 & -0.12 & -0.09 \\
\hline & $T_{n}$ & & 0.49 & 0.38 & & & & -0.13 & 0.31 & & & & -0.17 & & & 0.37 & -0.14 & 0.27 \\
\hline & $T_{\text {avg }}$ & & & 0.37 & & & & -0.15 & 0.13 & -0.18 & -0.16 & & -0.11 & & & -0.10 & -0.12 & -0.08 \\
\hline & DTR & & -0.19 & & -0.14 & & & -0.17 & -0.24 & -0.25 & -0.38 & & & 0.11 & -0.13 & -0.10 & -0.17 & -0.09 \\
\hline & $P$ & & & -2.17 & & 1.17 & -1.42 & & -2.40 & 1.65 & 1.10 & & 1.97 & 5.98 & -11.49 & -7.91 & 3.68 & \\
\hline & $Q$ & 1.82 & 5.09 & 5.37 & -2.50 & 11.35 & 14.67 & -46.60 & 41.71 & 35.22 & 10.17 & 5.29 & 0.75 & 1.91 & 15.72 & -1.40 & 19.35 & 4.25 \\
\hline \multirow[t]{6}{*}{ UIB-West } & $T_{x}$ & -0.14 & -0.11 & 0.23 & & & & -0.18 & & -0.22 & -0.21 & & -0.25 & -0.11 & & -0.09 & -0.12 & -0.10 \\
\hline & $T_{n}$ & & & & & & & -0.12 & 0.22 & & & & -0.18 & & & & -0.13 & \\
\hline & $T_{\text {avg }}$ & -0.15 & & 0.20 & & & & -0.13 & 0.13 & -0.19 & -0.19 & & -0.11 & & & & -0.11 & -0.07 \\
\hline & DTR & -0.18 & -0.20 & -0.10 & -0.16 & & & -0.17 & -0.24 & -0.27 & -0.38 & & & -0.10 & -0.13 & -0.10 & -0.19 & -0.10 \\
\hline & $P$ & & & -2.17 & -5.71 & 1.17 & & & -2.40 & 1.40 & & & 1.71 & 6.90 & -11.49 & -7.91 & 2.63 & \\
\hline & $Q$ & 2.45 & 1.37 & 5.43 & 2.42 & 61.35 & 54.89 & 0.21 & 42.93 & 28.24 & 13.68 & 5.87 & 1.38 & 2.00 & 23.43 & 44.18 & 17.71 & 22.17 \\
\hline \multirow{6}{*}{$\begin{array}{l}\text { UIB-West- } \\
\text { lower }\end{array}$} & $T_{x}$ & -0.17 & -0.10 & & & & & -0.16 & & -0.21 & -0.20 & & -0.28 & -0.16 & & -0.07 & -0.13 & -0.06 \\
\hline & $T_{n}$ & & -0.23 & & & & & -0.10 & 0.18 & & & & -0.12 & -0.18 & & -0.08 & -0.12 & \\
\hline & $T_{\text {avg }}$ & -0.15 & & & & & & -0.13 & 0.17 & & -0.19 & & -0.07 & -0.11 & & -0.06 & -0.11 & -0.07 \\
\hline & DTR & -0.15 & -0.20 & 0.18 & -0.18 & & & -0.13 & -0.18 & -0.36 & -0.25 & & & -0.12 & & -0.08 & -0.19 & -0.09 \\
\hline & $P$ & & & -2.29 & -5.71 & -4.60 & -2.18 & -1.90 & -1.80 & -2.11 & & & 0.42 & & -12.15 & -6.02 & -18.93 & -38.01 \\
\hline & $Q$ & 1.88 & 0.41 & 6.39 & -0.52 & 41.58 & $\mathbf{5 9 . 5 0}$ & 28.19 & 81.58 & 30.99 & 16.18 & 5.17 & 2.33 & 1.92 & 19.90 & 65.53 & 16.02 & 25.44 \\
\hline UIB-West- & $T_{x}$ & -0.14 & -0.11 & 0.23 & & & & -0.18 & & -0.22 & -0.21 & & -0.25 & -0.11 & & -0.09 & -0.12 & -0.10 \\
\hline upper & $T_{n}$ & & 0.22 & 0.13 & & & & -0.13 & 0.25 & 0.24 & & -0.18 & -0.24 & 0.17 & & 0.09 & 0.10 & 0.05 \\
\hline & $T_{\text {avg }}$ & -0.15 & & 0.20 & -0.09 & & & -0.13 & 0.08 & -0.20 & & & -0.13 & & & & -0.10 & \\
\hline & DTR & -0.21 & -0.22 & -0.11 & -0.18 & -0.25 & -0.28 & -0.19 & -0.36 & -0.28 & -0.52 & -0.38 & -0.17 & 0.06 & -0.16 & -0.11 & -0.19 & -0.11 \\
\hline & $P$ & 1.30 & & -1.94 & & 1.17 & 1.09 & 1.00 & & 1.40 & 0.31 & & 2.14 & 6.90 & -10.19 & -9.80 & 2.63 & \\
\hline & $Q$ & 1.24 & 1.02 & 1.39 & 2.38 & 16.85 & 12.38 & -25.48 & -15.50 & -1.28 & 0.69 & 0.98 & 0.52 & 0.55 & 7.76 & -3.68 & 0.45 & -1.25 \\
\hline
\end{tabular}

trend is found throughout the year, except for spring, where no signal is evident.

Moreover, field-significant climatic trends are mostly in qualitative agreement with the trends in discharge from the corresponding regions. Such an agreement is high during summer, particularly for July, and during winter, for March.
The few exceptions to such consistency are the subregions of Himalaya, UIB-West and UIB-West-lower, for which, in spite of the field-significant cooling in July, discharge is still increasing. However, the magnitude of increase in July discharge has substantially dropped when compared to the previous (June) and following (August) months. Such a sub- 
stantial drop in July discharge increase rate is again consistent with the field-significant cooling in July for the UIBWest and UIB-West-lower. Further, besides substantial cooling (warming) in September (March), the most prominent decrease in discharge is observed in July, while it increases in May, suggesting them to be months of effective cooling and warming, respectively. Generally, periods of runoff decrease (in a sequence) span from May to September for the Karakoram, June to September for the UIB-Central, July to August for the western Karakoram and UIB-West-upper, July to November for the Astore and only over July for the Hindukush and UIB. UIB-West-lower and Himalaya suggest a decrease in discharge during the months of April and February, respectively.

\section{Discussion}

\subsection{Cooling trends}

Observed long-term summer and autumn (or monsoon) cooling is mostly consistent with the earlier reports for the study basin (Fowler and Archer, 2005, 2006; Khattak et al., 2011; Sheikh et al., 2009), as well as those for the neighboring regions, such as Nepal, Himalayas (Sharma et al., 2000; Cook et al., 2003), northwest India (Kumar et al., 1994), the Tibetan Plateau (Liu and Chen, 2000), central China (Hu et al., 2003), and central Asia (Briffa et al., 2001).

Over the 1995-2012 period, field-significant cooling observed mostly in July, September and October for all UIB subregions coincides with the monsoonal onset and retreat months and, most importantly, with the main glacier melt season, thus negatively affecting the glacier melt runoff. The observed cooling phenomenon is generally attributed to the incursions of the South Asian summer monsoonal system and its precipitation (Cook et al., 2003) into the Karakoram and the UIB-West, which presently seems to be accelerated in view of the observed increase in cloud cover, precipitation and number of wet days (Bocchiola and Diolaiuti, 2013). Since summer precipitation over the UIB is partly received from the westerly disturbances (Wake, 1987), the observed cooling may also be attributed to the enhanced influence of the westerly disturbances during summer months, as during winter and spring (Madhura et al., 2015). Nevertheless, the observed increase in cloud cover leads to reduction of incident downward radiation and results in cooling (or less warming) of $T_{x}$. Forsythe et al. (2015) consistently observed the influence of cloud radiative effect on the nearsurface air temperature over the UIB. The enhanced cloudy conditions most probably are responsible for initial warming in $T_{n}$ through longwave cloud radiative effect, and when such conditions persist for a longer time, $T_{x}$ and $T_{n}$ more likely tend to cool. Under the clear-sky conditions, cooling in $T_{x}$ further continues as a result of evaporative cooling of the moisture-surplus surface under precipitation event (Wang et al., 2014) or due to irrigation (Kueppers et al., 2007). Han and Yang (2013) found irrigation expansion over Xinjiang, China, as a major cause of observed cooling in $T_{\mathrm{avg}}, T_{x}$ and $T_{n}$ during May-September over the period 1959-2006. Further, a higher drop in $T_{n}$ observed over UIB-West-lower during winter may be attributed to intense nighttime cooling of the deforested, and thus moisture-deficient, bare soil surface, which is exposed to direct daytime solar heating as explained by Yadav et al. (2004). The relevance of such hypotheses for the UIB further needs a detailed investigation of the landatmosphere processes and feedbacks using high-resolution climate model simulations with explicitly resolved convections, which is beyond the scope of our analysis.

\subsection{Warming trends}

Long-term warming during November-May is generally found to be consistent with earlier reports of warming (Fowler and Archer, 2005, 2006; Sheikh et al., 2009; Khattak et al., 2011; Río et al., 2013) as well as with decreasing snow cover in spring (1967-2012) over the Northern Hemisphere and worldwide (IPCC, 2013) and in winter (2001-2012) over the study region (Hasson et al., 2014b). Consistent with the findings of Sheikh et al. (2009) and Río et al. (2013), warming dominates in the spring months, where it is fieldsignificant in March over almost all identified subregions of the UIB. Under the drying spring scenario, less cloudy conditions associated with increasing number of dry days for the westerly precipitation regime (Hasson et al., 2016a; Hasson, 2016a) together with the snow-albedo feedback can partly explain spring warming. Contrary to long-term warming trends analyzed here or to those previously reported, a field-significant cooling is found for winter, which is consistently observed over the eastern United States, southern Canada and much of northern Eurasia (Cohen et al., 2012).

\subsection{Wetting and drying trends}

Field-significant increasing precipitation for the subregions of relatively higher latitudes (Hindukush and UIB-Central, and thus for the UIB-West-upper, Karakoram and the whole UIB) may be attributed to the enhanced late-monsoonal or westerly precipitation regimes at high-altitude stations. However, a shift of the long-term summer (June-August) wetting to drying at the low-altitude stations over the period 19952012 indicates a recent transition towards weaker monsoonal influence therein.

The field-significant precipitation increase during winter but decrease during spring indicates certain changes within the westerly precipitation regime. The field-significant spring drying (except for Karakoram) is mainly consistent with the weakening and northward shift of the midlatitude storm track (Bengtsson et al., 2006) and also with increasing number of spring dry days (Hasson et al., 2016a; Hasson, 2016a). On the other hand, observed winter precipitation increase for relatively high-latitudinal subregions is more consistent with 
the observed more frequent incursions of the westerly disturbances therein (Cannon et al., 2015; Madhura et al., 2015). Nevertheless, in view of the enhanced influence of prevailing weather systems and certain changes expected in their seasonality/intermittency under changing climate (Hasson et al., 2016a; Hasson, 2016a), we speculate significant changes in the timings of the meltwater availability from the UIB. Such a hypothesis can be tested by assessing changes in the seasonality of observed precipitation and runoff.

\subsection{Water availability}

The long-term discharge tendencies are consistent with earlier reports from Khattak et al. (2011) for Indus at Kachura and UIB, and from Farhan et al. (2014) for Astore. Similarly, increasing and decreasing discharge trends from Shyok and Hunza sub-basins, respectively, are consistent with Mukhopadhyay et al. (2015). The discharge trends from Shigar region, though statistically insignificant, are only partially consistent with Mukhopadhyay and Khan (2014), exhibiting agreement for an increasing trend in June and August but a decreasing trend in July and September. Further, prominent shifts of the long-term trends of increasing melt season discharge into decreasing over the period 19952012 for mostly the glacier-fed subregions (Indus at Kachura, Indus at Partab Bridge, eastern, central and the whole of Karakoram and UIB-Central) may attribute to higher summer cooling together with certain changes in prevailing precipitation regimes.

Over the 1995-2012 period, significant decreasing trend in July discharge is most probably attributed to observed July cooling, which, though less prominent than cooling in September, is much effective as it coincides with the main glacier melt season. A drop in July discharge further indicates reduced meltwater availability but at the same time positive basin storage, particularly under prevailing wetter conditions. Similarly, increasing discharge during May and June most likely is due to the observed warming, which, though less prominent than warming in March, is very effective since it coincides with the snowmelt season. This suggests an early melt of snow and subsequent increase in the meltwater availability but, concurrently, a lesser amount of snow available for the subsequent melt season. These seasonally distinct changes place emphasis on the separate assessments of snow and glacier melt regimes, for which an adequate choice is the hydrological models, which are able to independently simulate snow and glacier melt processes, e.g., the University of British Columbia (UBC) watershed model. Based on the UBC model, Hasson (2016b) recently confirmed our findings that the continuation of prevailing early melt season warming will yield an increased and early snowmelt runoff, but in stark contrast, mid- to late melt season cooling will result in a decreased and delayed glacier melt runoff in the near future. Such changes in both snow and glacier melt regimes all together can result in a sophisticated alteration of the hydro- logical regimes of the UIB and, subsequently, the timings of the downstream water availability.

Although the discharge change pattern seems to be more consistent with the field-significant temperature trends, indicating cryospheric melt as a dominating factor in determining the UIB discharge variability, it can also be substantially influenced by changes in the precipitation regimes. For instance, monsoonal offshoots intruding into the study region paradoxically result in declining river discharge (Archer, 2004). In fact, the high albedo of fresh snow reduces the incident energy, which results in an immediate drop in the melt. The fresh snow also insulates the underlying glacier/ice, slowing down the whole melt process until earlier albedo rates are achieved. Thus, melting of cryosphere and subsequent water availability are also inversely correlated with the number of snowfall events/days during the melt season (Wendler and Weller, 1974; Ohlendorf et al., 1997).

In view of the sparse observational network analyzed here, we need to clarify that the observed cooling and warming is only an aspect of the widespread changes prevailing over the wide-extent UIB. This is highly relevant for UIBCentral, where we have only one station each from the eastern and central Karakoram (UIB-Central) that is not exclusively representative of the hydro-climatic state of the corresponding subregion. Thus, field-significant results for the whole Karakoram are mainly dominated by the contribution of relatively large number of stations from the western Karakoram. Nevertheless, reports of increasing end-ofsummer snow cover and falling regional snow line altitudes (Minora et al., 2013; Hasson et al., 2014b; Tahir et al., 2016), increasing or stable glacial extents (Hewitt, 2005; Scherler et al., 2011; Bhambri et al., 2013; Minora et al., 2013), and possibly a non-negative glacier mass balance within eastern and central Karakoram (Gardelle et al., 2013 - in contrast to a shorter period - Kääb et al., 2015), local climate change narratives (Gioli et al., 2013) and overall simulated reduced near-future water availability for the UIB (Hasson, 2016b) reinforce our presented findings.

We find a common response of hydroclimatic changes from a certain set of months, which are different than those (DJF, MAM, JJA, SON) typically considered for winter, spring, summer and autumn, respectively. This places emphasis on analyzing the hydroclimatic observations at higher temporal resolution to robustly assess the subtle signals of change.

It should be mentioned that the hydro-climatic regime of the UIB is substantially controlled by the interaction of large-scale circulation modes and their associated precipitation regimes, which are in turn controlled by global indices such as NAO and El Niño-Southern Oscillation. However, the time period covered by our presented analysis is not long enough to unravel the natural variability signals from the transient climate change. These phenomena need to be better investigated over the longer and spatially complete observational record, preferably including an extensive database 
of validated proxy observations since the challenges of short and sparse robust in situ observations are most likely to remain invariant for the UIB.

\section{Conclusions}

We present a first comprehensive and systematic hydroclimatic trend analysis for the UIB based on 10 stream flow, 6 low-altitude manual and 12 high-altitude automatic weather stations. Results suggest general narrowing of DTR throughout the year except for March and May, which is significant in September followed by February. Such a year-round narrowing of DTR is further found field-significant for almost all subregions, and is mainly associated with either higher cooling in $T_{x}$ than in $T_{n}$ or cooling in $T_{x}$ but warming in $T_{n}$.

Cooling at most of the stations is observed during the monsoon and the main glacier melt season (July-October), which is significant in September followed by July. Further, locally observed cooling is found field-significant for almost all subregions in July, September and October and, on a seasonal timescale, for autumn and summer. In contrast, good agreement regarding local warming, though mostly insignificantly observed in March, May and November, is field-significant in March for most of the subregions. For precipitation, March, spring and summer feature field-significant drying for all the subregions except those within the Karakoram, while winter, autumn and September mostly feature wetting of high (drying of low) altitudinal subregions. The change pattern in discharge out of corresponding subregions seems more consistent with the field-significant tendencies in temperature than in precipitation, where discharge is either decreasing or weakly increasing (increasing) in response to cooling (warming), particularly in the month of July (May). These findings, though constrained by short and sparse observational dataset, suggest distinct changes for the snow and glacier melt seasons, indicating at present strengthening of the nival but suppression of the glacial melt regime, altering the overall hydrology of the UIB. The presented findings largely contribute to the ongoing research on understanding the melt runoff dynamics within the UIB and in addressing the hydroclimatic explanation of the "Karakoram Anomaly".

Data availability. The observed hydroclimatic data used in the paper are available with the data collection agencies of the Water and Power Development Authority (WAPDA) and the Pakistan Meteorological Department (PMD) and can be obtained upon request.

Competing interests. The authors declare that they have no conflict of interest.
Acknowledgements. The authors acknowledge the Pakistan Meteorological Department (PMD) and the Water and Power Development Authority (WAPDA), Pakistan, for providing the hydroclimatic data. The work was supported through the Cluster of Excellence "CliSAP" (EXC177), Universität Hamburg, funded through the German Science Foundation (DFG). Shabeh ul Hasson and Jürgen Böhner also acknowledge the support of the German Federal Ministry of Education and Research (BMBF) through the Bundle Project CLASH (Climate variability and landscape dynamics in Southeast-Tibet and the eastern Himalaya during the Late Holocene reconstructed from tree rings, soils and climate modeling).

Edited by: A. Kleidon

Reviewed by: B. Bookhagen and four anonymous referees

\section{References}

Ahmad, Z., Hafeez, M., and Ahmad, I.: Hydrology of mountainous areas in the upper Indus Basin, Northern Pakistan with the perspective of climate change, Environ. Monit. Assess., 184, 52555274, 2012.

Ali, G., Hasson, S., and Khan, A. M.: Climate Change: Implications and Adaptation of Water Resources in Pakistan, GCISC-RR-13, Global Change Impact Studies Centre (GCISC), Islamabad, Pakistan, 2009.

Archer, D. R.: Contrasting hydrological regimes in the upper Indus Basin, J. Hydrol., 274, 19-210, 2003.

Archer, D. R.: Hydrological implications of spatial and altitudinal variation in temperature in the Upper Indus Basin, Nord. Hydrol., 35, 209-222, 2004.

Archer, D. R. and Fowler, H. J.: Spatial and temporal variations in precipitation in the Upper Indus Basin, global teleconnections and hydrological implications, Hydrol. Earth Syst. Sci., 8, 47-61, doi:10.5194/hess-8-47-2004, 2004.

Arendt, A., Bliss, A., Bolch, T., Cogley, J. G., Gardner, A. S., Hagen, J.-O., Hock, R., Huss, M., Kaser, G., Kienholz, C., Pfeffer, W. T., Moholdt, G., Paul, F., Radić, V., Andreassen, L., Bajracharya, S., Barrand, N. E., Beedle, M., Berthier, E., Bhambri, R., Brown, I., Burgess, E., Burgess, D., Cawkwell, F., Chinn, T., Copland, L., Davies, B., De Angelis, H., Dolgova, E., Earl, L., Filbert, K., Forester, R., Fountain, A. G., Frey, H., Giffen, B., Glasser, N., W. Q., Guo, Gurney, S., Hagg, W., Hall, D., Haritashya, U. K., Hartmann, G., Helm, C., Herreid, S., Howat, I., Kapustin, G., Khromova, T., König, M., Kohler, J., Kriegel, D., Kutuzov, S., Lavrentiev, I., LeBris, R., Liu, S. Y., Lund, L., Manley, W., Marti, R., Mayer, C., Miles, E. S., Li, X., Menounos, B., Mercer, A., Mölg, N., Mool, P., Nosenko, G., Negrete, A., Nuimura, T., Nuth, C., Pettersson, R., Racoviteanu, A., Ranzi, R., Rastner, P., Rau, F., Raup, B., Rich, J., Rott, H., Sakai, A., Schneider, C., Seliverstov, Y., Sharp, M., Sigurðsson, O., Stokes, C., Way, R. G., Wheate, R., Winsvold, S., Wolken, G., Wyatt, F., and Zheltyhina, N.: Randolph Glacier Inventory - A Dataset of Global Glacier Outlines: Version 5.0, Digital Media, Global Land Ice Measurements from Space, Boulder, Colorado, USA, 2015.

Batura Investigations Group: The Batura Glacier in the Karakoram Mountains and its variations, Scient. Sin., 22, 958-974, 1979. 
Bengtsson, L., Hodges, I. K., and Roeckner, E.: Storm tracks and climate change, J. Climate, 19, 3518-3542, 2006.

Bhambri, R., Bolch, T., Kawishwar, P., Dobhal, D. P., Srivastava, D., and Pratap, B.: Heterogeneity in glacier response in the upper Shyok valley, northeast Karakoram, The Cryosphere, 7, 13851398, doi:10.5194/tc-7-1385-2013, 2013.

Bocchiola, D. and Diolaiuti, G.: Recent (1980-2009) evidence of climate change in the upper Karakoram, Pakistan, Theor. Appl. Climatol., 113, 611-641, 2013.

Briffa, K. R., Osborn, T. J., Schweingruber, F. H., Harris, I. C., Jones, P. D., Shiyatov, S. G., and Vaganov, E. A.: Low frequency temperature variations from northern tree ring density network, J. Geophys. Res., 106, 2929-2941, 2001.

Cannon, F., Carvalho, L. M. V., Jones, C., and Bookhagen, B.: Multi-annual variations in winter westerly disturbance activity affecting the Himalaya, Clim. Dynam., 44, 441-455, doi:10.1007/s00382-014-2248-8, 2015.

Cohen, J. L., Furtado, J. C., Barlow, M. A., Alexeev, V. A., and Cherry, J. E.: Arctic warming, increasing snow cover and widespread boreal winter cooling, Environ. Res. Lett., 7, 014007 , doi:10.1088/1748-9326/7/1/014007, 2012.

Cook, E. R., Krusic, P. J., and Jones, P. D.: Dendroclimatic signals in long tree-ring chronologies from the Himalayas of Nepal, Int. J. Climatol., 23, 707-732, 2003.

Douglas, E. M., Vogel, R. M., and Kroll, C. N.: Trends in floods and low flows in the United States: impact of spatial correlation, J. Hydrol., 240, 90-105, 2000.

Efron, B.: Bootstrap methods: another look at the jackknife, Ann. Stat., 7, 1-26, 1979.

Farhan, S. B., Zhang, Y., Ma, Y., Guo, Y., and Ma, N.: Hydrological regimes under the conjunction of westerly and monsoon climates: a case investigation in the Astore Basin, Northwestern Himalaya, Clim. Dynam., 44, 3015-3032, doi:10.1007/s00382014-2409-9, 2014.

Forsythe, N., Hardy, A. J., Fowler, H. J., Blenkinsop, S., Kilsby, C. G., Archer, D. R., and Hashmi, M. Z.: A Detailed Cloud Fraction Climatology of the Upper Indus Basin and Its Implications for Near-Surface Air Temperature, J. Climate, 28, 3537-3556, 2015.

Fowler, H. J. and Archer, D. R.: Hydro-climatological variability in the Upper Indus Basin and implications for water resources, Regional Hydrological Impacts of Climatic Change - Impact Assessment and Decision Making, in: Proceedings of symposium S6, Seventh IAHS Scientific Assembly, Foz do Iguaçu, Brazil, 2005.

Fowler, H. J. and Archer, D. R.: Conflicting Signals of Climatic Change in the Upper Indus Basin, J. Climate, 9, 4276-4293, 2006.

Gardelle, J., Berthier, E., Arnaud, Y., and Kääb, A.: Region-wide glacier mass balances over the Pamir-Karakoram-Himalaya during 1999-2011, The Cryosphere, 7, 1263-1286, doi:10.5194/tc7-1263-2013, 2013.

Gioli, G., Khan, T., and Scheffran, J.: Climatic and environmental change in the Karakoram: making sense of community perceptions and adaptation strategies, Reg. Environ. Change, 14, 11511162, 2013.

Han, S. and Yang, Z.: Cooling effect of agricultural irrigation over Xinjiang, Northwest China from 1959 to 2006, Environ. Res. Lett., 8, 024039, doi:10.1088/1748-9326/8/2/024039, 2013.
Hasson, S.: Seasonality of Precipitation over Himalayan Watersheds in CORDEX South Asia and their Driving CMIP5 Experiments, Atmosphere, 7, 123, doi:10.3390/atmos7100123, 2016a.

Hasson, S.: Future Water Availability from HindukushKarakoram-Himalaya upper Indus Basin under Conflicting Climate Change Scenarios, Climate, 4, 1-28, $2016 \mathrm{~b}$.

Hasson, S., Lucarini, V., Pascale, S., and Böhner, J.: Seasonality of the hydrological cycle in major South and Southeast Asian river basins as simulated by PCMDI/CMIP3 experiments, Earth Syst. Dynam., 5, 67-87, doi:10.5194/esd-5-67-2014, 2014a.

Hasson, S., Lucarini, V., Khan, M. R., Petitta, M., Bolch, T., and Gioli, G.: Early 21st century snow cover state over the western river basins of the Indus River system, Hydrol. Earth Syst. Sci., 18, 4077-4100, doi:10.5194/hess-18-4077-2014, 2014b.

Hasson, S., Pascale, S., Lucarini, V., and Böhner, J.: Seasonal cycle of precipitation over major river basins in South and Southeast Asia: A review of the CMIP5 climate models data for present climate and future climate projections, Atmos. Res., 180, 42-63, 2016 a.

Hasson, S., Gerlitz, L., Scholten, T., Schickhoff, U., and Böhner, J.: Recent Climate Change over High Asia, in: Climate Change, Glacier Response, and Vegetation Dynamics in the Himalaya, Springer International Publishing, Switzerland, 29-48, $2016 \mathrm{~b}$.

Hess, A., Lyer, H., and Malm, W.: Linear trend analysis: a comparison of methods, Atmos. Environ., 35, 5211-5222, 2001.

Hewitt, K.: The Karakoram anomaly? Glacier expansion and the 'elevation effect', Karakoram Himalaya, Mt. Res. Dev., 25, 332340, 2005.

Hewitt, K.: Glacier change, concentration, and elevation effects in the Karakoram Himalaya, Upper Indus Basin, Mt. Res. Dev., 31, 188-200, doi:10.1659/MRD-JOURNAL-D-11-00020.1, 2011.

Houze, R. A., Rasmussen, K. L., Medina, S., Brodzik, S. R., and Romatschke, U.: Anomalous Atmospheric Events Leading to the Summer 2010 Floods in Pakistan, B. Am. Meteorol. Soc., 92, 291-298, 2011.

$\mathrm{Hu}, \mathrm{Z}$. Z., Yang, S., and Wu, R. G.: Long-term climate variations in China and global warming signals, J. Geophys. Res., 108, 4614, doi:10.1029/2003JD003651, 2003.

Immerzeel, W. W., Droogers, P., de Jong, S. M., and Bierkens, M. F. P.: Large-scale monitoring of snow cover and runoff simulation in Himalayan river basins using remote sensing, Remote Sens. Environ., 113, 40-49, 2009.

IPCC: Climate Change 2013: The Physical Science Basis, in: Contribution of Working Group I to the Fifth Assessment Report of the Intergovernmental Panel on Climate Change, edited by: Stocker, T. F., Qin, D., Plattner, G.-K., Tignor, M., Allen, S. K., Boschung, J., Nauels, A., Xia, Y., Bex, V., and Midgley, P. M., Cambridge University Press, Cambridge, UK and New York, NY, USA, 1535 pp., 2013.

Jaagus, J.: Climatic changes in Estonia during the second half of the 20th century in relationship with changes in large-scale atmospheric circulation, Theor. Appl. Climatol., 83, 77-88, 2006.

Kääb, A., Treichler, D., Nuth, C., and Berthier, E.: Brief Communication: Contending estimates of 2003-2008 glacier mass balance over the Pamir-Karakoram-Himalaya, The Cryosphere, 9, 557564, doi:10.5194/tc-9-557-2015, 2015.

Kendall, M. G.: Rank Correlation Methods, Griffin, London, UK, 1975. 
Khattak, M. S., Babel, M. S., and Sharif, M.: Hydrometeorological trends in the upper Indus River Basin in Pakistan, Clim. Res., 46, 103-119, doi:10.3354/cr00957, 2011.

Klein Tank, A. M. G., Zwiers, F. W., and Zhang, X.: Guidelines on analysis of extremes in a changing climate in support of informed decisions for adaptation, WCDMP-72, WMOTD/No. 1500, WMO Publications Board, Geneva, Switzerland, 56 pp., 2009.

Kueppers, L. M., Snyder, M. A., and Sloan, L. C.: Irrigation cooling effect: Regional climate forcing by land-use change, Geophys. Res. Lett., 34, L03703, doi:10.1029/2006GL028679, 2007.

Kulkarni, A. and von Storch, H.: Monte Carlo experiments on the effect of serial correlation on the Mann-Kendall test of trend, Meteorol. Z., 4, 82-85, 1995.

Kumar, K. R., Kumar, K. K., and Pant, G. B.: Diurnal asymmetry of surface temperature trends over India, Geophys. Res. Lett., 21, 677-680, 1994.

Lacombe, G. and McCartney, M.: Uncovering consistencies in Indian rainfall trends observed over the last half century, Climatic Change, 123, 287-299, 2014.

Liu, X. and Chen, B.: Climatic warming in the Tibetan Plateau during recent decades, Int. J. Climatol., 20, 1729-1742, 2000.

Madhura, R. K., Krishnan, R., Revadekar, J. V., Mujumdar, M., and Goswami, B. N.: Changes in western disturbances over the Western Himalayas in a warming environment, Clim. Dynam., 44, 1157-1168, 2015.

Mann, H. B.: Nonparametric tests against trend, Econometrica, 13, 245-259, 1945.

Minora, U., Bocchiola, D., D’Agata, C., Maragno, D., Mayer, C., Lambrecht, A., Mosconi, B., Vuillermoz, E., Senese, A., Compostella, C., Smiraglia, C., and Diolaiuti, G.: 2001-2010 glacier changes in the Central Karakoram National Park: a contribution to evaluate the magnitude and rate of the "Karakoram anomaly", The Cryosphere Discuss., 7, 2891-2941, doi:10.5194/tcd-72891-2013, 2013.

MRI (Mountain Research Initiative) EDW (Elevation Dependent Warming) Working Group: Pepin, N., Bradley, R. S., Diaz, H. F., Baraer, M., Caceres, E. B., Forsythe, N., Fowler, H., Greenwood, G., Hashmi, M. Z., Liu, X. D., Miller, J. R., Ning, L., Ohmura, A., Palazzi, E., Rangwala, I., Schöner, W., Severskiy, I., Shahgedanova, M., Wang, M. B., Williamson, S. N., and Yang, D. Q.: Elevation-dependent warming in mountain regions of the world, Nat. Clim. Change, 5, 424-430, doi:10.1038/nclimate2563, 2015.

Mukhopadhyay, B. and Khan, A.: Rising river flows and glacial mass balance in central Karakoram, J. Hydrol., 513, 192-203, 2014.

Mukhopadhyay, B. and Khan, A.: A reevaluation of the snowmelt and glacial melt in river flows within Upper Indus Basin and its significance in a changing climate, J. Hydrol., 119-132, 2015.

Mukhopadhyay, B., Khan, A., and Gautam, R: Rising and falling river flows: contrasting signals of climate change and glacier mass balance from the eastern and western Karakoram, Hydrolog. Sci. J., 60, 2062-2085, doi:10.1080/02626667.2014.947291, 2015.

Ohlendorf, C., Niessenn, F., and Weissert, H.: Glacial Varve thickness and 127 years of instrumental climate data: a comparison, Climatic Change, 36, 391-411, 1997.
Revadekar, J. V., Hameed, S., Collins, D., Manton, M., Sheikh, M., Borgaonkar, H. P., Kothawale, D. R., Adnan, M., Ahmed, A. U., Ashraf, J., Baidya, S., Islam, N., Jayasinghearachchi, D., Manzoor, N., Premalal, K. H. M. S., and Shreshta, M. L.: Impact of altitude and latitude on changes in temperature extremes over South Asia during 1971-2000, Int. J. Climatol., 33, 199-209, doi:10.1002/joc.3418, 2013.

Río, S. D., Iqbal, M. A., Cano-Ortiz, A., Herrero, L., Hassan, A., and Penas, A.: Recent mean temperature trends in Pakistan and links with teleconnection patterns, Int. J. Climatol., 33, 277-290, doi:10.1002/joc.3423, 2013.

Rivard, C. and Vigneault, H.: Trend detection in hydrological series: when series are negatively correlated, Hydrol. Process., 23, 2737-2743, 2009.

Scherler, D., Bookhagen, B., and Strecker, M. R.: Spatially variable response of Himalayan glaciers to climate change affected by debris cover, Nat. Geosci., 4, 156-159, doi:10.1038/ngeo1068, 2011.

Sen, P. K.: Estimates of the regression coefficient based on Kendall's tau, J. Am. Stat. Assoc., 63, 1379-1389, 1968.

Sharma, K. P., Moore, B., and Vorosmarty, C. J.: Anthropogenic, climatic and hydrologic trends in the Kosi basin, Himalaya, Climatic Change, 47, 141-165, 2000.

Sheikh, M. M., Manzoor, N., Adnan, M., Ashraf, J., and Khan, A. M.: Climate Profile and Past Climate Changes in Pakistan, GCISC-RR-01, Global Change Impact Studies Centre (GCISC), Islamabad, Pakistan, 2009.

SIHP: Snow and Ice Hydrology, Pakistan Phase-II Final Report to CIDA, IDRC File No. 88-8009-00, KIG 3H9, Report No. IDRC. 54, International Development Research Centre, Ottawa, Ontario, Canada, 1997.

Syed, F. S., Giorgi, F., Pal, J. S., and King, M. P.: Effect of remote forcing on the winter precipitation of central southwest Asia Part 1: Observations, Theor. Appl. Climatol., 86, 147-160, doi:10.1007/s00704-005-0217-1, 2006.

Tabari, H. and Talaee, P. H.: Recent trends of mean maximum and minimum air temperatures in the western half of Iran, Meteorol. Atmos. Phys., 111, 121-131, 2011.

Tahir, A. A., Adamowski, J. F., Chevallier, P., Haq, A. U., and Terzago, S.: Comparative assessment of spatiotemporal snow cover changes and hydrological behavior of the Gilgit, Astore and Hunza River basins (Hindukush-Karakoram-Himalaya region, Pakistan), Meteorol. Atmos. Phys., 128, 793-811, doi:10.1007/s00703-016-0440-6, 2016.

Theil, H.: A rank-invariant method of linear and polynomial regression analysis, I, II, III. Nederl. Akad. Wetensch, Proc. 53, Amsterdam, 386-392, 512-525, 1397-1412, 1950.

Vogel, R. M. and Kroll, C. N.: Low-flow frequency analysis using probability plot correlation coefficients, J. Water Res. Pl. Manage., 115, 338-357, 1989.

Von Storch, H.: Misuses of statistical analysis in climate research, in: Analysis of Climate Variability: Applications of Statistical Techniques, edited by: von Storch, H. and Navarra, A., SpringerVerlag, Berlin, 11-26, 1995.

Wake, C. P.: Snow accumulation studies in the central Karakoram, Proc. Eastern Snow Conf. 44th Annual Meeting Fredericton, Canada, 19-33, 1987. 
Wake, C. P.: Glaciochemical investigations as a tool to determine the spatial variation of snow accumulation in the Central Karakoram, Northern Pakistan, Ann. Glaciol., 13, 279-284, 1989.

Wang, F., Zhang, C., Peng, Y., and Zhou, H.: Diurnal temperature range variation and its causes in a semiarid region from 1957 to 2006, Int. J. Climatol., 34, 343-354, doi:10.1002/joc.3690, 2014.

Wang, X. L.: Penalized maximal $F$-test for detecting undocumented mean shifts without trend-change, J. Atmos. Ocean. Tech., 25, 368-384, doi:10.1175/2007JTECHA982.1, 2008.

Wang, X. L. and Feng, Y.: RHtestsV3 user manual, report, Clim. Res. Div., Atmos. Sci. and Technol. Dir., Sci. and Technol. Branch, Environ. Canada, Gatineau, Quebec, Canada, 26 pp., available at: http://etccdi.pacificclimate.org/software.shtml (last access: 15 November 2014), 2009.

Wang, X. L. and Swail, V. R.: Changes of Extreme Wave Heights in Northern Hemisphere Oceans and Related Atmospheric Circulation Regimes, J. Climate, 14, 2204-2221, 2001.

Wendler, G. and Weller, G.: A Heat-Balance Study on McCall Glacier, Brooks Range, Alaska: A Contribution to the International Hydrological Decade, J. Glaciol., 13, 13-26, 1974.

Winiger, M., Gumpert, M., and Yamout, H.: KarakorumHindukush-western Himalaya: assessing high-altitude water resources, Hydrol. Process., 19, 2329-2338, doi:10.1002/hyp.5887, 2005.
Wu, H., Soh, L.-K., Samal, A., Chen, X.-H.: Trend Analysis of Streamflow Drought Events in Nebraska, Water Resour. Manage., 22, 145, doi:10.1007/s11269-006-9148-6, 2008.

Yadav, R. R., Park, W.-K., Singh, J., and Dubey, B.: Do the western Himalayas defy global warming?, Geophys. Res. Lett., 31, L17201, doi:10.1029/2004GL020201, 2004.

Yue, S. and Wang, C. Y.: Regional streamflow trend detection with consideration of both temporal and spatial correlation, Int. J. Climatol., 22, 933-946, doi:10.1002/joc.781, 2002.

Yue, S., Pilon, P., Phinney, B., and Cavadias, G.: The influence of autocorrelation on the ability to detect trend in hydrological series, Hydrol. Process., 16, 1807-1829, 2002.

Yue, S., Pilon, P., and Phinney, B.: Canadian streamflow trend detection: impacts of serial and cross-correlation, Hydrolog. Sci. J., 48, 51-63, doi:10.1623/hysj.48.1.51.43478, 2003.

Zhai, P. Zhang, X., Wan, H., and Pan, X.: Trends in Total Precipitation and Frequency of Daily Precipitation Extremes over China, J. Climate, 18, 1096-1108, doi:10.1175/JCLI-3318.1, 2005.

Zhang, X., Vincent, L. A., Hogg, W. D., and Niitsoo, A.: Temperature and precipitation trends in Canada during the 20th century, Atmos.-Ocean, 38, 395-429, 2000. 